University of Nebraska - Lincoln

DigitalCommons@University of Nebraska - Lincoln

USGS Staff -- Published Research

US Geological Survey

2009

Concentrations of Cadmium, Cobalt, Lead, Nickel, and Zinc in Blood and Fillets of Northern Hog Sucker (Hypentelium nigricans) from Streams Contaminated by Lead-Zinc Mining: Implications for Monitoring

Christopher J. Schmitt

U.S. Geological Survey, cjschmitt@usgs.gov

W. G. Brumbaugh

Columbia Environmental Research Center, US Geological Survey, 4200 New Haven Road, Columbia, MO

T.W.May

Columbia Environmental Research Center, US Geological Survey, 4200 New Haven Road, Columbia, MO

Follow this and additional works at: http:// digitalcommons.unl.edu/usgsstaffpub

Schmitt, Christopher J.; Brumbaugh, W. G.; and May, T. W., "Concentrations of Cadmium, Cobalt, Lead, Nickel, and Zinc in Blood and Fillets of Northern Hog Sucker (Hypentelium nigricans) from Streams Contaminated by Lead-Zinc Mining: Implications for Monitoring" (2009). USGS Staff -- Published Research. 882.

http://digitalcommons.unl.edu/usgsstaffpub/882

This Article is brought to you for free and open access by the US Geological Survey at DigitalCommons@University of Nebraska - Lincoln. It has been accepted for inclusion in USGS Staff -- Published Research by an authorized administrator of DigitalCommons@University of Nebraska - Lincoln. 


\title{
Concentrations of Cadmium, Cobalt, Lead, Nickel, and Zinc in Blood and Fillets of Northern Hog Sucker (Hypentelium nigricans) from Streams Contaminated by Lead-Zinc Mining: Implications for Monitoring
}

\author{
C. J. Schmitt · W. G. Brumbaugh · T. W. May
}

Received: 8 August 2008/Accepted: 20 January 2009/Published online: 11 February 2009 (C) US Government 2009

\begin{abstract}
Lead $(\mathrm{Pb})$ and other metals can accumulate in northern hog sucker (Hypentelium nigricans) and other suckers (Catostomidae), which are harvested in large numbers from Ozark streams by recreational fishers. Suckers are also important in the diets of piscivorous wildlife and fishes. Suckers from streams contaminated by historic $\mathrm{Pb}$-zinc $(\mathrm{Zn})$ mining in southeastern Missouri are presently identified in a consumption advisory because of $\mathrm{Pb}$ concentrations. We evaluated blood sampling as a potentially nonlethal alternative to fillet sampling for $\mathrm{Pb}$ and other metals in northern hog sucker. Scaled, skin-on, bone-in "fillet" and blood samples were obtained from northern hog suckers $(n=75)$ collected at nine sites representing a wide range of conditions relative to $\mathrm{Pb}-\mathrm{Zn}$ mining in southeastern Missouri. All samples were analyzed for cadmium $(\mathrm{Cd})$, cobalt $(\mathrm{Co}), \mathrm{Pb}$, nickel $(\mathrm{Ni})$, and $\mathrm{Zn}$. Fillets were also analyzed for calcium as an indicator of the amount of bone, skin, and mucus included in the samples. $\mathrm{Pb}, \mathrm{Cd}, \mathrm{Co}$, and $\mathrm{Ni}$ concentrations were typically higher in blood than in fillets, but $\mathrm{Zn}$ concentrations were similar in both sample types. Concentrations of all metals except $\mathrm{Zn}$ were typically higher at sites located downstream from active and historic $\mathrm{Pb}-\mathrm{Zn}$ mines and related facilities than at nonmining sites. Blood concentrations of $\mathrm{Pb}, \mathrm{Cd}$, and Co were highly correlated with corresponding fillet concentrations; log-log linear regressions between concentrations in the two sample types explained $94 \%$ of the variation for $\mathrm{Pb}, 73-83 \%$ of the variation for $\mathrm{Co}$, and $61 \%$ of the variation for $\mathrm{Cd}$. In contrast, relations for $\mathrm{Ni}$ and $\mathrm{Zn}$ explained $<12 \%$ of the total variation. Fillet $\mathrm{Pb}$ and
\end{abstract}

C. J. Schmitt $(\bowtie)$. W. G. Brumbaugh · T. W. May

Columbia Environmental Research Center, US Geological

Survey, 4200 New Haven Road, Columbia, MO 65201, USA

e-mail: cjschmitt@usgs.gov calcium concentrations were correlated $(r=0.83)$, but only in the 12 fish from the most contaminated site; concentrations were not significantly correlated across all sites. Conversely, fillet $\mathrm{Cd}$ and calcium were correlated across the range of sites $(r=0.78)$, and the inclusion of calcium in the fillet-to-blood relation explained an additional $12 \%$ of the total variation in fillet Cd. Collectively, the results indicate that blood sampling could provide reasonably accurate and precise estimates of fillet $\mathrm{Pb}, \mathrm{Co}$, and $\mathrm{Cd}$ concentrations that would be suitable for identifying contaminated sites and for monitoring, but some fillet sampling might be necessary at contaminated sites for establishing consumption advisories.

The killing of potentially valuable fish for the sole purpose of monitoring contaminant concentrations is becoming increasingly unpopular among natural resource management agencies and their constituents, and it is inappropriate for rare, threatened, or endangered species. Previous studies have demonstrated the utility of muscle biopsy sampling as an alternative to sampling fillets and whole fish for monitoring mercury $(\mathrm{Hg})$ and selenium $(\mathrm{Se})$ and for obtaining samples for genetic and other biologic analyses (summarized by Schmitt and Brumbaugh 2007).The analysis of scales and fin tissue has also been evaluated for a number of metals including lead $(\mathrm{Pb})$ and $\mathrm{Hg}$ (Sauer and Watabe 1989; Rashed 2001a, b; Lake et al. 2006; Gremillion et al. 2005; Rolfhus et al. 2008). Blood sampling has long been employed for monitoring $\mathrm{Pb}$ in humans (Barbosa et al. 2005) and in wildlife (Henny 2003). The utility of blood sampling for monitoring $\mathrm{Pb}$, cadmium $(\mathrm{Cd})$, and $\mathrm{Hg}$ has been demonstrated in a few fish species (Brumbaugh et al. 2005; Schmitt and Brumbaugh 2007), but investigation for other metals has been limited. 
We measured concentrations of $\mathrm{Pb}, \mathrm{Zn}, \mathrm{Cd}$, cobalt (Co), and nickel $(\mathrm{Ni})$ in blood and fillet samples of northern hog sucker (Hypentilium nigricans; henceforth "hog sucker") from streams in southeastern Missouri, a highly mineralized area that has been mined extensively for $\mathrm{Pb}, \mathrm{Zn}$, and other metals. Hog sucker and other sucker species $(\mathrm{Ca}$ tostomidae) are harvested in large numbers from area streams by recreational fishers. Concentrations of $\mathrm{Pb}$ and other metals associated with $\mathrm{Pb}-\mathrm{Zn}$ mining are typically higher in suckers than in many other species that inhabit Ozark streams (Czarneski 1985; Gale et al. 2004; Schmitt et al. 2007a), and they have been consequently identified in a consumption advisory (Missouri Department of Health and Senior Services [MDHSS] 2008). Our primary objective was to evaluate blood as a potentially nonlethal alternative to fillet sampling for mining-related metals in hog sucker. Secondary objectives were to examine the influence of fish length, weight, age, and calcium (Ca) content on fillet metal concentrations (Schmitt and Finger 1987) as well as to provide contemporary data for consideration relative to consumption guidelines and advisories.

\section{Materials and Methods}

The procedures described here conform to the recommendations of the American Society of Ichthyologists and Herpetologists (ASIH), the American Fisheries Society (AFS), and the American Institute of Fishery Research Biologists (AIFRB; 2004) as well as with all guidelines for the humane treatment of test organisms during culture and experimentation of the United States Geological Survey (USGS) and our laboratory. The study was conducted in accordance with a Scientific Investigator Permit from the United States National Park Service (NPS) and a Wildlife Collectors Permit from the Missouri Department of Conservation (MDC). Use of trade, product, or firm names does not constitute endorsement.

\section{Study Area and Collection Sites}

The "Old Lead Belt" of southeastern Missouri (Fig. 1) was mined until the early 1970s. Most mining preceded environmental regulation and used comparatively inefficient extraction technology, which left behind extensive environmental contamination (Schmitt et al. 2005, 2006, 2007a, b; Gale et al. 2004; Brumbaugh et al. 2005, 2007; MDHSS 2008). The "New Lead Belt" or "Viburnum Trend," which is located west of the Old Lead Belt (Fig. 1), was developed in the 1960s and is currently active. Mining in the Viburnum Trend proceeded under contemporary environmental regulations and used modern extraction technology
(Wixson 1978). Nevertheless, increased metal concentrations and a range of biologic effects have been documented in streams draining the Viburnum Trend (Schmitt et al. 1993, 2007a, b; Besser et al. 2007, 2009; Allert et al. 2008, in press). Exploration for additional $\mathrm{Pb}-\mathrm{Zn}$ deposits has also occurred within the Mark Twain National Forest, southwest of the Viburnum Trend in an environmentally sensitive area that hosts a national park (Ozark National Scenic Riverways [ONSR]) and the federally designated Eleven Point Wild and Scenic River (Fig. 1). The surface watersheds of these streams are sparsely populated and mostly forested, and they contain few point-sources of contamination (Petersen et al. 1998). Although the five sites in the protected areas currently represent reference conditions with respect to $\mathrm{Pb}-\mathrm{Zn}$ mining, the exploration area lies within the surface watershed of Eleven Point River (EPR) and the groundwater recharge areas of large springs that feed both the Current River and the EPR, which could be affected by future mining (Imes et al. 2007).

Hog suckers were collected in 2005 at five sites located within federally protected areas: (1) on the Current River (CRC, CRW, and CRP) and Jacks Fork (JF) within the ONSR; (2) on the EPR. Fish were also collected at a site located on the Big River (BR) downstream of the Old Lead Belt (Fig. 1 and Table 1). In 2007, fish were collected from Strother Creek (SC) and Logan Creek (LC) at sites located downstream of active $\mathrm{Pb}-\mathrm{Zn}$ mines and mine-related facilities in the Viburnum Trend (Fig. 1 and Table 1).

\section{Sample Containers and Cleaning Procedures}

Blood samples were stored in $1.8-\mathrm{mL}$ polyethylene cryogenic vials $\left(\right.$ Nunc $^{\circledR}$ 347627; Nalge-Nunc International, Naperville, IL). The vials and caps were submerged overnight in a bath of $4 \mathrm{M}$ nitric acid and $2 \mathrm{M}$ hydrochloric acid followed by overnight soaking in deionized water. They were then triple-rinsed with high-purity deionized water $(>15 \mathrm{M} \Omega / \mathrm{cm})$, dried in a HEPA-filtered air oven, capped, and stored in zipper-seal polyethylene bags. Fillet samples were stored in 1-quart zipper-seal polyethylene freezer storage bags, which were not precleaned. Samples were processed and handled in the field with stainless-steel forceps and knives that were washed in laboratory detergent and rinsed with tap water and methanol between fish to prevent cross-contamination. Titanium and glass instruments were used in the laboratory.

\section{Field Procedures}

Hog suckers were collected by electrofishing. The nominal collection target was 12 fish representing the size range typically harvested by recreational fishers (200 to $500 \mathrm{~mm}$ total length [TL]) from each site sampled in 2005 and 6 fish 
Fig. 1 Map of the study area showing collection sites (as identified in Table 1), the Eleven Point Wild and Scenic River, and the Ozark National Scenic Riverways

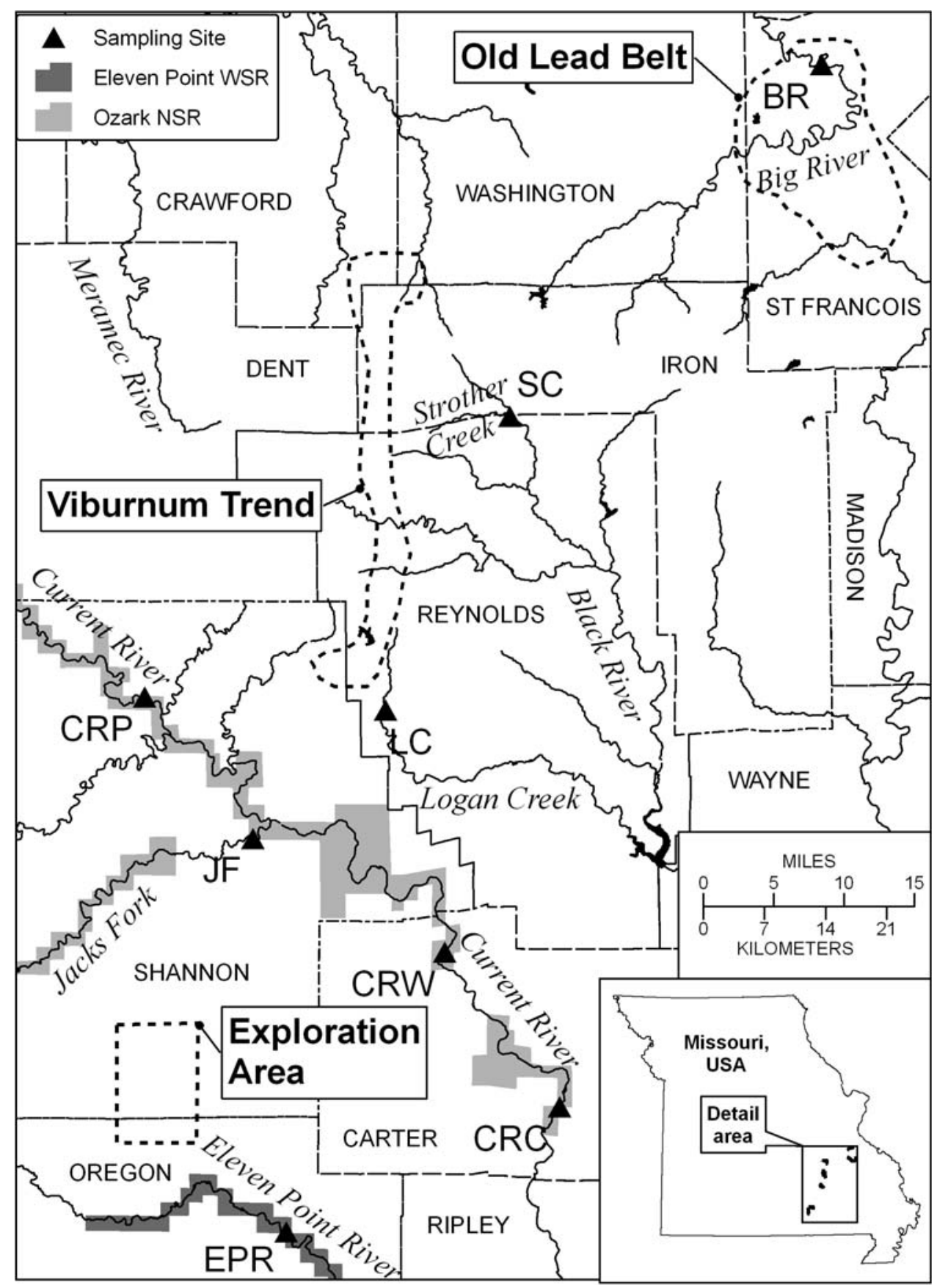

from each site sampled in 2007. A wide size range was sought at each site to facilitate the development and evaluation of regression models relating metal concentrations to fish size and age. Fish were processed according to a protocol intended to minimize external contamination (Brumbaugh et al. 2005; Schmitt et al. 2007a; Schmitt and Brumbaugh 2007). All contact surfaces were covered with polyethylene or other material that was replaced between fish to prevent cross-contamination. Blood (nominally $1 \mathrm{~mL}$ ) was obtained by caudal veinipuncture using a chilled, heparinized $(6 \mathrm{IU} / \mathrm{mL})$ disposable needle and syringe, then dispensed into a precleaned polyethylene vial. Triplicate blood samples were prepared from one large fish from each of several sites as part of the quality-control (QC) program by dispensing three $1.0-$ to $1.5-\mathrm{mL}$ subsamples from a single syringe containing 3 to $5 \mathrm{~mL}$ blood into separate containers. After blood collection, the fish was killed with a blow to the head, weighed $(\mathrm{g})$, and measured (TL in $\mathrm{mm}$ ). A scale sample was removed from the area below the dorsal fin for age determination (Jearld 1983), and the fish was scaled. Using a knife, a skin-on/ bone-in fillet (the locally preferred preparation method) 
Table 1 Fish collection sites in southern Missouri, United States and sampling dates

\begin{tabular}{|c|c|c|c|c|c|c|}
\hline Site & River or stream & Location & Site type & County & Latitude and longitude & Date \\
\hline EPR & Eleven Point River & Turner's Mill & $\mathrm{P}$ & Oregon & $36^{\circ} 45^{\prime \prime} 56.7^{\prime \prime} \mathrm{N}, 91^{\circ} 16^{\prime} 01.0^{\prime \prime} \mathrm{W}$ & 08-29-2005 \\
\hline $\mathrm{CRC}$ & Current River & Cataract Landing & $\mathrm{P}$ & Carter & $36^{\circ} 53^{\prime} 22.2^{\prime \prime} \mathrm{N}, 90^{\circ} 54^{\prime} 47.3^{\prime \prime} \mathrm{W}$ & 08-30-2005 \\
\hline CRW & Current River & Waymeyer Landing & $\mathrm{P}$ & Carter & $37^{\circ} 03^{\prime} 03.2^{\prime \prime} \mathrm{N}, 91^{\circ} 03^{\prime} 16.8^{\prime \prime} \mathrm{W}$ & 08-31-2005 \\
\hline CRP & Current River & Presley Center & $\mathrm{P}$ & Shannon & $37^{\circ} 19^{\prime} 12.6^{\prime \prime} \mathrm{N}, 91^{\circ} 28^{\prime} 29.8^{\prime \prime} \mathrm{W}$ & 09-07-2005 \\
\hline $\mathrm{JF}$ & Jacks Fork & Shawnee Creek & $\mathrm{P}$ & Shannon & $37^{\circ} 10^{\prime} 21.3^{\prime} \mathrm{N}, 91^{\circ} 18^{\prime} 00.6^{\prime \prime} \mathrm{W}$ & 09-08-2005 \\
\hline $\mathrm{BR}$ & Big River & St. Francois State Park & OLB & St. Francois & $37^{\circ} 57^{\prime} 23.7^{\prime \prime} \mathrm{N}, 90^{\circ} 32^{\prime} 29.2^{\prime \prime} \mathrm{W}$ & $10-04-2005$ \\
\hline $\mathrm{LC}$ & Logan Creek & Near Corridon & VT & Reynolds & $37^{\circ} 18^{\prime} 07.8^{\prime \prime} \mathrm{N}, 91^{\circ} 07^{\prime} 35.6^{\prime \prime} \mathrm{W}$ & $10-02-2007$ \\
\hline SC & Strother Creek & Near Redmondville & VT & Iron & $37^{\circ} 36^{\prime} 06.9^{\prime \prime} \mathrm{N}, 90^{\circ} 57^{\prime} 28.8^{\prime \prime} \mathrm{W}$ & $10-02-2007$ \\
\hline
\end{tabular}

$P$ protected area (no $\mathrm{Pb}-\mathrm{Zn}$ mining), $O L B$ Old Lead Belt (historical $\mathrm{Pb}-\mathrm{Zn}$ mining), $V T$ Viburnum Trend (active $\mathrm{Pb}-\mathrm{Zn}$ mining)

a As documented by global positioning system receiver $( \pm<10 \mathrm{~m}$ ); data from the World Geodetic System 1984 (WGS 84 )

was obtained from the left side of the fish, and the sex of each fish collected in 2005 was determined by gonadal observation. Fillets from EPR fish included the caudal peduncle and ribs, and those from the other sites represented a smaller area of each fish. The sample was placed in a zipper-seal polyethylene bag and frozen (dry ice) or chilled (wet ice). On return to the laboratory, the blood and fillet samples were stored frozen $\left(-20{ }^{\circ} \mathrm{C}\right)$ until analysis.

\section{Laboratory Methods and Quality Assurance}

All samples were freeze dried. The moisture content of blood and fillet samples collected in 2005 was determined from weight loss during lyophylization. The moisture content of 2007 samples was not determined. The frozen fillet samples were rinsed twice in their zipper-seal bags with high-purity deionized water to remove surface contamination, then drained thoroughly and transferred to a preweighed glass dish, chopped into $2-\mathrm{cm}^{2}$ pieces, weighed, and lyophilized. Fillet triplicates were prepared in the laboratory during processing. Blood samples were thawed, and 0.1- to 0.2-mL subsamples were pipetted into preweighed vials, weighed, and lyophilized. Before analysis, dried fillet samples were transferred to a heavy-duty zipper-seal polyethylene bag in which they were pulverized and hand mixed to produce a uniform, fibrous powder. Dried blood samples were crushed to a fine powder with a polystyrene microspatula just before analysis. Dried, homogenized samples were digested in $\mathrm{HNO}_{3}$ and $\mathrm{H}_{2} \mathrm{O}_{2}$ (Brumbaugh et al. 2005). Digestates were analyzed for $\mathrm{Ca}$ (fillet samples only), $\mathrm{Co}, \mathrm{Pb}, \mathrm{Cd}, \mathrm{Zn}$, and $\mathrm{Ni}$ by inductively coupled plasma-mass spectrometry (ICP-MS) (Brumbaugh et al. 2005; Besser et al. 2007). Concentrations were reported as micrograms per gram $(\mu \mathrm{g} / \mathrm{g})$ dry weight $(\mathrm{dw})$. Results for replicated samples were reported as the arithmetic mean of the replicates.

In addition to field replicates, laboratory QC included regular measurements of instrument calibration standards and analyses of analytic replicates, reagent blanks, fortified (spiked) samples, and certified reference materials. A calibration blank and an independent calibration verification standard were analyzed every 10 samples to confirm the calibration status of the inductively coupled plasma-mass spectrometer throughout the instrumental analyses using SPEX ClaritasPPT Instrument Check Standard 1 (CL-ICS1; Spec Certiprep, Metuchen, NJ). As a check for potential interferences, dilution percent differences based on 5-fold dilutions of the sample digestates were determined. Additional QC measures incorporated at or after sample digestion included digestion blanks, certified reference materials, replicates, and predigestion/postdigestion spikes. Reference materials for blood samples included (1) the United States National Institute of Standards and Technology SRM 1640, Seronorm 201705; (2) Trace Elements in Whole Blood (2005 samples only; SERO AS, Billingstad, Norway); (3) International Atomic Energy Agency CRM A-13 (animal blood, 2007 samples only); and (4) ClinChek 8841, Whole Blood, Control Level 2 (Recipe Chemicals, Munich, Germany). Reference materials for fillet samples were National Research Council Canada CRM DORM-2 (dogfish muscle) and International Atomic Energy Agency Reference Material 407 (whole fish). Samples were digested and analyzed in four (blood) or five (fillets) blocks (groups), each of which included appropriate QC samples. Instrument and method detection limits (MDLs) and method quantitation limits were estimated for each element in each block based on the SDs of the measured concentrations in blanks and standards (Table 2). The QC parameters were generally within acceptable ranges, and most analyte concentrations in blood and fillet samples exceeded the MDLs (Table 2). The exception was one block of blood samples in which a small amount of $\mathrm{Pb}$ and $\mathrm{Ni}$ were detected in the blanks, which resulted in higher MDLs for these samples than for the samples in the other three blocks (Table 2). All censored (less than MDL) values were associated with samples representing fish from 
Table 2 Ranges of MDLs ( $\mu \mathrm{g} / \mathrm{g} \mathrm{dw}^{\mathrm{a}, \mathrm{b}}$ ) for elemental analyses in four (blood) or five (fillets) blocks and number of samples and percentage of each type in which the analytes were detected

\begin{tabular}{llllll}
\hline Analyte & \multicolumn{3}{l}{ Blood } & & \multicolumn{2}{l}{ Fillet } \\
\cline { 2 - 3 } & MDL range & $n(\%)$ & & MDL range & $\mathrm{n}(\%)$ \\
\hline $\mathrm{Ca}$ & $\mathrm{NA}$ & $\mathrm{NA}$ & & $3.20-11.0^{\mathrm{b}}$ & $77(100)$ \\
$\mathrm{Co}$ & $0.001-0.017$ & $89(100)$ & & $0.006-0.007$ & $77(100)$ \\
$\mathrm{Ni}$ & $0.013-0.063$ & $74(83)$ & & $0.014-0.053$ & $70(91)$ \\
$\mathrm{Zn}$ & $0.17-0.89$ & $89(100)$ & & $0.10-0.38$ & $77(100)$ \\
$\mathrm{Cd}$ & $0.002-0.009$ & $89(100)$ & & $0.003-0.006$ & $74(96)$ \\
$\mathrm{Pb}$ & $0.007-0.059$ & $69(78)$ & $0.005-0.017$ & $64(83)$ \\
\hline
\end{tabular}

NA not analyzed

${ }^{\mathrm{a}} \mathrm{MDL}=3 \times\left(\mathrm{SD}_{\mathrm{b}}^{2}+\mathrm{SD}_{\mathrm{s}}^{2}\right)^{1 / 2}$, where $\mathrm{SD}_{\mathrm{b}}=\mathrm{SD}$ of digestion blanks $(n=3)$ and $\mathrm{SD}_{\mathrm{s}}=\mathrm{SD}$ of a low level standard diluted 100fold $(n=3)$

${ }^{\mathrm{b}} \mathrm{Ca} \mathrm{MDL}=\mathrm{mg} / \mathrm{g} \mathrm{dw}$

protected areas (i.e., reference sites). Overall, the QC analyses indicated an acceptable level of sensitivity, precision, and accuracy for these samples, in which concentrations of some analytes were comparatively low.

\section{Data Set Composition and Statistical Analyses}

In 2005, 63 fish were collected from 6 sites. Male and female fish were obtained at all sites, but the sex of two small fish from CRW and three fish from JF could not be determined in the field. A preliminary statistical analysis of the 2005 data indicated that female fish were slightly (but not significantly) longer and heavier, but not older, than male fish. Among the variables measured in blood and fillet samples (metals and moisture), only fillet $\mathrm{Zn}$ concentrations differed significantly, and the difference was small ( $10 \%$ greater in male than female fish). Consequently, sex was not considered in subsequent statistical analyses.

The 89 blood and 77 fillet samples in the complete data set represented a total of 75 fish from 8 sites. The target numbers of fish (12 in 2005 and 6 in 2007) were obtained from each site except EPR, where only 3 were obtained (Table 3). Fish were 226 to $467 \mathrm{~mm}$ in TL, weighed 144 to $1330 \mathrm{~g}$, and were 1 to 9 years old. On average, fish from the small streams sampled in 2007 (LC and SC) were shorter, lighter, and younger than those from the larger streams sampled in 2005 (Table 3). Moisture content in the 2005 samples was extremely consistent (Table 3) and therefore was not measured in the 2007 samples. Wetweight (ww) metal concentrations in the 2005 samples were computed using the moisture content of each blood and fillet sample. The $2007 \mathrm{ww}$ concentrations were computed using the mean moisture content of the 2005 samples $\quad$ (fillet $=79.7 \pm 0.1 \%, \quad$ blood $=86.6 \pm 0.3 \%$, $n=63)$. The molar ratio of $\mathrm{Pb}$ to $\mathrm{Ca}[\mathrm{Pb}] /[\mathrm{Ca}]$ in the fillet samples was computed based on the measured $\mathrm{dw}$ concentrations and the atomic weights of $\mathrm{Pb}$ (207.19) and $\mathrm{Ca}$ (40.08). Censored values were excluded from these computations.

Differences among sites were tested statistically with analysis of variance (ANOVA) and Fisher's least significant difference tests. Analysis of covariance, correlation analysis (Pearson), linear regression, and stepwise multiple linear regression were used to evaluate relations between blood and fillet metals concentrations and the influence of $\mathrm{TL}$, weight, age, and $\mathrm{Ca}$ content on fillet metal concentrations. SAS software (version 9.1; SAS, Carey, NC) was used for all statistical analyses. Summary statistics comparing the measured versus predicted concentrations were computed for each statistically significant regression model. Based on preliminary statistical analysis indicating a need to stabilize the variance of most variables, metal concentrations, $[\mathrm{Pb}] /[\mathrm{Ca}]$, TL, weight, and age were $\log _{10^{-}}$ transformed before analysis. Percent moisture was transformed using the angular transformation. Although arithmetic means and SEs are presented, all statistical tests were based on transformed data. A nominal $p$ value of $\alpha=0.05$ was used to judge statistical significance unless otherwise indicated. Censored values were excluded from all statistical analyses, graphs, and tables. Because of the
Table 3 Numbers of specimens and arithmetic mean $( \pm \mathrm{SE})$ of TL, weight, age, and blood and fillet moisture content of northern hog suckers from sites in southeastern Missouri

NA not analyzed

${ }^{\text {a }}$ Protected area

b Old Lead Belt (historical mining)

c Viburnum Trend (active or recent mining)

\begin{tabular}{lclllll}
\hline Site & $n$ & $\begin{array}{l}\text { Total length } \\
(\mathrm{mm})\end{array}$ & $\begin{array}{l}\text { Weight } \\
(\mathrm{g})\end{array}$ & Age (y) & \multicolumn{2}{l}{ Moisture (\%) } \\
\cline { 5 - 7 } & & & & & Blood & Fillet \\
\hline $\mathrm{EPR}^{\mathrm{a}}$ & 3 & $347 \pm 38$ & $483 \pm 169$ & $3.7 \pm 0.3$ & $86.2 \pm 0.9$ & $78.8 \pm 0.2$ \\
$\mathrm{CRC}^{\mathrm{a}}$ & 12 & $372 \pm 11$ & $548 \pm 55$ & $3.2 \pm 0.3$ & $84.9 \pm 0.2$ & $79.3 \pm 0.2$ \\
$\mathrm{CRW}^{\mathrm{a}}$ & 12 & $354 \pm 19$ & $538 \pm 72$ & $2.8 \pm 0.4$ & $86.6 \pm 0.5$ & $79.3 \pm 0.3$ \\
$\mathrm{CRP}^{\mathrm{a}}$ & 12 & $359 \pm 15$ & $542 \pm 69$ & $3.9 \pm 0.5$ & $87.3 \pm 0.7$ & $79.7 \pm 0.2$ \\
$\mathrm{JF}^{\mathrm{a}}$ & 12 & $316 \pm 21$ & $416 \pm 69$ & $2.5 \pm 0.3$ & $86.9 \pm 0.4$ & $79.8 \pm 0.2$ \\
$\mathrm{BR}^{\mathrm{b}}$ & 12 & $283 \pm 80$ & $267 \pm 27$ & $2.8 \pm 0.2$ & $87.2 \pm 0.6$ & $80.7 \pm 0.1$ \\
$\mathrm{LC}^{\mathrm{c}}$ & 6 & $271 \pm 10$ & $218 \pm 23$ & $4.0 \pm 0.1$ & NA & NA \\
$\mathrm{SC}^{\mathrm{c}}$ & 6 & $258 \pm 3$ & $200 \pm 48$ & $1.8 \pm 0.4$ & NA & NA \\
\hline
\end{tabular}


high degree of consistency in the blood and fillet moisture values, the statistical results were nearly identical for the ww and $d w$ analyses. Therefore, and except where indicated, the dw data are presented.

Measured and estimated concentrations of $\mathrm{Pb}$ and $\mathrm{Cd}$ in hog sucker fillets were compared with relevant human consumption guidelines, which vary among agencies and jurisdictions. $\mathrm{Pb}$ and $\mathrm{Cd}$ are nevertheless universally recognized as ubiquitous contaminants to which people are exposed in many ways. Many criteria for fish and other foods are therefore defined as or developed from ingestion rates (summarized by Van Oostdam et al. 1999; Schmitt et al. 2006; Leblond et al. 2008); information on exposure pathways other than diet (air, dust, smoking, etc.) are required for complete evaluation (United States Environmental Protection Agency [USEPA] 1994). A maximum residue level (MRL) of $0.2 \mu \mathrm{g} / \mathrm{g}$ ww $(0.99 \mu \mathrm{g} / \mathrm{g} \mathrm{dw})$ for $\mathrm{Pb}$ in fish was proposed by the Food and Agricultural Organization of the United Nations (FAO) and the World Health Organization (WHO), but it was not adopted (FAO/WHO 1999); the current MRL for $\mathrm{Pb}$ in fish is $0.3 \mu \mathrm{g} / \mathrm{g}$ ww ([1.48 $\mu \mathrm{g} / \mathrm{g} \mathrm{dw}$ at $79.7 \%$ moisture]; FAO/WHO 2007), which was used to establish the current Missouri advisory (MDHSS 2008). Other current standards and criteria for $\mathrm{Pb}$ in fish are higher (Australia-New Zealand Food Authority 2002; Dural et al. 2006).

For Cd, MRLs of 0.05 to $0.10 \mu \mathrm{g} / \mathrm{g}$ ww ( 0.25 to $0.49 \mu \mathrm{g}$ / $\mathrm{g} \mathrm{dw}$ ) in fish and invertebrates have been proposed (FAO/ WHO 1998), but the MRL was not adopted for fish; however, in Turkey the standard is $0.1 \mu \mathrm{g} / \mathrm{g}$ ww $(0.49 \mu \mathrm{g} / \mathrm{g}$ $\mathrm{dw}$; Dural et al. 2006). In the United States, screening values for Cd in fish weighing $4.0 \mu \mathrm{g} / \mathrm{g}$ ww $(19.7 \mu \mathrm{g} / \mathrm{g} \mathrm{dw}$ at $79.7 \%$ moisture) for recreational fishers and $0.491 \mu \mathrm{g} / \mathrm{g}$ ww $(2.42 \mu \mathrm{g} / \mathrm{g} \mathrm{dw})$ for subsistence fishers have been established (USEPA 2000a). There are also risk-based criteria for $\mathrm{Cd}$ in fish (USEPA 2000b) ranging from $0.088 \mu \mathrm{g} / \mathrm{g}$ ww $(0.43 \mu \mathrm{g} / \mathrm{g} \mathrm{dw}: \leq 16 \mathrm{meals} / \mathrm{mo})$ to $5.6 \mu \mathrm{g} / \mathrm{g}$ ww $(27.6 \mu \mathrm{g} / \mathrm{g} \mathrm{dw}$; no consumption). The United States Food and Drug Agency (USFDA) provides "guidance levels" for $\mathrm{Pb}, \mathrm{Cd}$, and $\mathrm{Ni}$, which accumulate in invertebrates (bivalves and crustacean), but $\mathrm{Hg}$ is the only metal for which an enforceable "action level" has been established for fish (USFDA 2000, 2001). Cobalt, Ni, and Zn are essential elements; although they may be toxic at high concentrations, these metals do not typically accumulate to harmful concentrations in the edible parts of fish (e.g., Sidwell et al. 1978; FAO 1983; Schmitt and Finger 1987; Vos et al. 1986; Watanabe et al. 2003).

Metals in fish also represent a threat to piscivorous wildlife and to the fish themselves. We therefore estimated $\mathrm{Pb}$ concentrations in whole hog suckers from blood $\mathrm{Pb}$ concentrations using previously determined regression relations (Schmitt et al. 1993). These estimates were compared with toxicity benchmarks from the scientific literature and to no-effect hazard concentrations developed for wildlife using toxicity reference values and food chain analysis, the lowest of which was $1.1 \mu \mathrm{g} / \mathrm{g} \mathrm{dw}$ (Schmitt et al. 2006, 2008). Relations between blood and whole-fish concentrations were not available for the other metals analyzed.

\section{Results}

Calcium

Calcium $(\mathrm{Ca})$ was detected in all fillet samples. Concentrations differed significantly among sites; they were higher in the three fish from EPR than those from all other sites (Table 4), presumably because of the larger area of the fish sampled. Concentrations were also slightly higher in fish from BR, LC, and SC, which were smaller than those from the other sites (Table 3). Consequently, fillet $\mathrm{Ca}$ concentrations were (weakly) negatively correlated with total length when examined across all sites (Table 5).

\section{Lead and $[\mathrm{Pb}] /[\mathrm{Ca}]$}

$\mathrm{Pb}$ concentrations exceeded the MDL in blood samples from 57 fish and fillet samples from 62 fish representing all eight sites. As noted previously, most of the censored values were from EPR, CRW, and CRC because of the combination of low concentrations and comparatively high MDL for one analytic block. On a dw basis, concentrations were typically 4-fold higher in blood than in fillet (Table 4). Concentrations in both sample types were significantly higher in fish from the three mining sites (BR, $\mathrm{SR}$, and LC) than in those from the protected areas (Table 4). Concentrations were almost 9-fold greater in blood and fillet samples from the sites in the Viburnum Trend (SC and LC) than from the protected areas, and they were 8-fold greater at BR than at SC and LC (Table 4).

Blood and fillet data from 48 fish representing all eight sites were available for regression and correlation analyses, but EPR was represented by only one fish, CRW by two, and CRC by five because of censoring. Measured $\mathrm{Pb}$ concentrations in the 48 blood and fillet samples were highly correlated (Table 5). A log-log linear model containing only blood $\mathrm{Pb}$ explained $94 \%$ of the total variation in fillet $\mathrm{Pb}$ (Fig. 2). No other variables were significant after accounting for blood $\mathrm{Pb}$. In general, this model accurately and precisely estimated fillet $\mathrm{Pb}$ concentrations across the range of measured concentrations (Fig. 2). The mean difference between predicted and measured fillet $\mathrm{Pb}$ concentrations based on this model was $<39 \%$ (Table 6). However, the mean 
Table 4 Arithmetic mean $( \pm \mathrm{SE}$ ) concentrations $(\mu \mathrm{g} / \mathrm{g} \mathrm{dw})$ of $\mathrm{Ca}, \mathrm{Co}, \mathrm{Cd}, \mathrm{Ni}, \mathrm{Pb}$, and $\mathrm{Zn}$ )in blood and fillet samples and $[\mathrm{Pb}] /[\mathrm{Ca}]$ in fillets

\begin{tabular}{|c|c|c|c|c|c|c|c|}
\hline Site and type & $\mathrm{Ca}$ & $\mathrm{Co}$ & $\mathrm{Cd}$ & $\mathrm{Ni}$ & Lead & $\mathrm{Zn}$ & {$[\mathrm{Pb}] /[\mathrm{Ca}]$} \\
\hline \multicolumn{8}{|l|}{ Blood } \\
\hline $\mathrm{EPR}^{\mathrm{a}}$ & NA & $0.30 \pm 0.04 \mathrm{~d}$ & $0.04 \pm 0.01 \mathrm{~cd}$ & $0.19 \pm 0.04 \mathrm{c}$ & $0.19 \mathrm{c}$ & $50.0 \pm 2.0 \mathrm{~b}$ & NA \\
\hline $\mathrm{CRC}^{\mathrm{a}}$ & NA & $0.48 \pm 0.05 \mathrm{c}$ & $0.06 \pm 0.01 \mathrm{bc}$ & $0.11 \pm 0.03 \mathrm{~d}$ & $0.08 \pm 0.01 \mathrm{~d}$ & $45.6 \pm 1.0 \mathrm{~b}$ & NA \\
\hline $\mathrm{CRW}^{\mathrm{a}}$ & NA & $0.35 \pm 0.03 \mathrm{~cd}$ & $0.04 \pm 0.01 \mathrm{~d}$ & $0.09 \pm 0.01 \mathrm{~d}$ & $0.08 \pm 0.02 \mathrm{~d}$ & $49.5 \pm 1.9 \mathrm{~b}$ & NA \\
\hline $\mathrm{CRP}^{\mathrm{a}}$ & NA & $0.41 \pm 0.05 \mathrm{~cd}$ & $0.02 \pm<0.01 \mathrm{~d}$ & $0.14 \pm 0.02 \mathrm{~cd}$ & $0.04 \pm 0.01 \mathrm{e}$ & $52.2 \pm 3.4 \mathrm{~b}$ & NA \\
\hline $\mathrm{JF}^{\mathrm{a}}$ & NA & $0.40 \pm 0.05 \mathrm{~cd}$ & $0.01 \pm<0.01 \mathrm{e}$ & $0.18 \pm 0.03 \mathrm{c}$ & $0.06 \pm 0.01 \mathrm{de}$ & $49.5 \pm 1.8 \mathrm{~b}$ & NA \\
\hline $\mathrm{BR}^{\mathrm{b}}$ & NA & $0.74 \pm 0.08 \mathrm{~b}$ & $0.14 \pm 0.05 \mathrm{~b}$ & $0.54 \pm 0.06 \mathrm{~b}$ & $7.03 \pm 0.63 \mathrm{a}$ & $46.1 \pm 1.3 \mathrm{~b}$ & NA \\
\hline $\mathrm{LC}^{\mathrm{c}}$ & NA & $0.97 \pm 0.04 \mathrm{~b}$ & $0.34 \pm 0.04 \mathrm{a}$ & $0.19 \pm 0.02 \mathrm{c}$ & $0.91 \pm 0.06 \mathrm{~b}$ & $59.4 \pm 1.2 \mathrm{a}$ & NA \\
\hline $\mathrm{SC}^{\mathrm{c}}$ & NA & $2.88 \pm 0.26 \mathrm{a}$ & $0.03 \pm<0.01 \mathrm{~d}$ & $0.92 \pm 0.14 \mathrm{a}$ & $0.81 \pm 0.10 \mathrm{~b}$ & $61.2 \pm 3.2 \mathrm{a}$ & NA \\
\hline$F$ & NA & $35.69 * *$ & $25.95 * *$ & $32.24 * *$ & $313.15 * *$ & $5.52 * *$ & NA \\
\hline$d f$ & NA & 7,67 & 7,67 & 7,56 & 7,49 & 7,67 & NA \\
\hline \multicolumn{8}{|l|}{ Fillet } \\
\hline $\mathrm{EPR}^{\mathrm{a}}$ & $6143 \pm 853 a$ & $0.05 \pm 0.01 \mathrm{~cd}$ & $0.07 \pm 0.03 \mathrm{ab}$ & $0.09 \mathrm{a}$ & $0.04 \pm 0.02 \mathrm{~d}$ & $57.4 \pm 9.2 \mathrm{~b}$ & $1.38 \pm 0.84 \mathrm{e}$ \\
\hline $\mathrm{CRC}^{\mathrm{a}}$ & $1486 \pm 162 \mathrm{e}$ & $0.05 \pm 0.01 \mathrm{~cd}$ & $0.02 \pm 0.01 \mathrm{c}$ & $0.09 \pm 0.01 \mathrm{a}$ & $0.02 \pm<0.01 \mathrm{e}$ & $44.7 \pm 1.9 \mathrm{~cd}$ & $2.43 \pm 0.50 \mathrm{~cd}$ \\
\hline $\mathrm{CRW}^{\mathrm{a}}$ & $1448 \pm 117 \mathrm{e}$ & $0.03 \pm<0.01 \mathrm{e}$ & $0.01 \pm<0.01 \mathrm{c}$ & $0.08 \pm 0.01 \mathrm{a}$ & $0.01 \pm<0.01 \mathrm{e}$ & $40.4 \pm 1.7 \mathrm{~d}$ & $1.93 \pm 0.43 \mathrm{~cd}$ \\
\hline $\mathrm{CRP}^{\mathrm{a}}$ & $1928 \pm 168 \mathrm{cde}$ & $0.06 \pm<0.01 \mathrm{~cd}$ & $0.02 \pm<0.01 \mathrm{c}$ & $0.06 \pm 0.01 \mathrm{a}$ & $0.02 \pm<0.01 \mathrm{e}$ & $39.4 \pm 1.6 \mathrm{~d}$ & $1.74 \pm 0.17 \mathrm{~d}$ \\
\hline $\mathrm{JF}^{\mathrm{a}}$ & $1891 \pm 234 \mathrm{de}$ & $0.04 \pm<0.01 \mathrm{de}$ & $0.01 \pm<0.01 \mathrm{c}$ & $0.07 \pm 0.01 \mathrm{a}$ & $0.03 \pm<0.01 \mathrm{~d}$ & $43.7 \pm 2.1 \mathrm{~cd}$ & $3.19 \pm 0.41 \mathrm{~d}$ \\
\hline $\mathrm{BR}^{\mathrm{b}}$ & $2513 \pm 197 \mathrm{bc}$ & $0.06 \pm<0.01 \mathrm{c}$ & $0.05 \pm 0.01 \mathrm{~b}$ & $0.07 \pm 0.01 \mathrm{a}$ & $1.71 \pm 0.18 \mathrm{a}$ & $49.0 \pm 2.5 \mathrm{bc}$ & $132.0 \pm 7.2 \mathrm{c}$ \\
\hline $\mathrm{LC}^{\mathrm{c}}$ & $3055 \pm 449 b$ & $0.10 \pm 0.01 \mathrm{~b}$ & $0.10 \pm 0.01 \mathrm{a}$ & $0.07 \mathrm{a}$ & $0.27 \pm 0.04 \mathrm{~b}$ & $54.8 \pm 1.6 \mathrm{~b}$ & $17.8 \pm 1.7 \mathrm{~b}$ \\
\hline $\mathrm{SC}^{\mathrm{c}}$ & $2258 \pm 267 \mathrm{bcd}$ & $0.25 \pm 0.03 \mathrm{a}$ & $0.01 \pm<0.01 \mathrm{c}$ & $0.11 \pm<0.01 \mathrm{a}$ & $0.15 \pm 0.03 \mathrm{c}$ & $68.7 \pm 4.0 \mathrm{a}$ & $14.9 \pm 4.3 \mathrm{~b}$ \\
\hline$F$ & $14.43 * *$ & $26.82 * *$ & $13.22 * *$ & $1.94 \mathrm{~ns}$ & $154.37 * *$ & $11.45 * *$ & $104.51 * *$ \\
\hline$d f$ & 7,67 & 7,67 & 13,64 & 7,54 & 7,54 & 7,67 & 7,54 \\
\hline
\end{tabular}

Also shown are ANOVA results, as F-values $(* * p<0.01)$ and degrees of freedom $(d f)$, comparing site means. Within each sample type, means followed by the same letter (online alphabets) are not significantly different $(p>0.05)$

NA not analyzed

${ }^{\text {a }}$ Protected area

b Old Lead Belt (historical mining)

c Viburnum Trend (active or recent mining)

Table 5 Pearson correlation coefficients ${ }^{\mathrm{a}}$ between the indicated variables (all log-transformed)

\begin{tabular}{|c|c|c|c|c|c|c|c|c|c|}
\hline & TL & Weight & Age & Fillet $\mathrm{Ca}$ & Blood Co & Blood Cd & Blood Ni & Blood $\mathrm{Pb}$ & Blood Zn \\
\hline TL & - & $0.99 * *$ & $0.72 * *$ & ND & $-0.30 * *$ & -0.01 & $-0.57 * *$ & $-0.43 * *$ & $-0.33 * *$ \\
\hline Weight & $0.99 *$ & - & $0.72 * *$ & ND & $-0.31 * *$ & -0.03 & $-0.57 * *$ & $-0.43 * *$ & $-0.33 * *$ \\
\hline Age & $0.72 * *$ & $0.72 * *$ & - & ND & -0.08 & $-0.39 * *$ & $-0.36 * *$ & -0.10 & -0.17 \\
\hline Fillet $\mathrm{Ca}$ & -0.22 & -0.22 & 0.15 & - & ND & ND & ND & ND & ND \\
\hline Fillet Co & -0.21 & $-0.23 *$ & 0.01 & $0.33 * *$ & $0.85 * * \mathrm{~b}$ & $0.37 * *$ & $0.69 * *$ & $0.50 * *$ & $0.52 * *$ \\
\hline Fillet $\mathrm{Cd}$ & -0.08 & 0.08 & $0.36 * *$ & $0.54 * *$ & $0.37 * *$ & $0.78 * *$ & 0.23 & $0.59 * *$ & 0.06 \\
\hline Fillet Nil & $-0.29 *$ & $-0.35^{* *}$ & $-0.33 * *$ & 0.15 & 0.09 & -0.17 & 0.19 & 0.68 & $0.25^{*}$ \\
\hline Fillet $\mathrm{Pb}$ & $-0.46^{* *}$ & $-0.45 * *$ & -0.05 & $0.42 * *$ & $0.36 * *$ & $0.53 * *$ & 0.11 & $0.97 * *$ & 0.03 \\
\hline Fillet Zn & $-0.57 * *$ & $-0.58 * *$ & $-0.28 *$ & $0.35 * *$ & $0.42 * *$ & 0.23 & $0.27 *$ & $0.38 * *$ & $0.34 * *$ \\
\hline$[\mathrm{Pb}] /[\mathrm{Ca}]$ & $-0.44 * *$ & $-0.43 * *$ & -0.08 & 0.20 & $0.36^{* *}$ & $0.43 * *$ & 0.09 & $0.97 * *$ & $-0.32 * *$ \\
\hline
\end{tabular}

ND not determined

a $r ; * p<0.01, * p<0.05$, all $n \geq 47$

b With all observations $(n=75) ; r=0.93$ with one outlier deleted

deviation was heavily influenced by one large fillet $\mathrm{Pb}$ value from $\mathrm{BR}$, which was underestimated by approximately $50 \%$, and by proportionally large deviations in fish with low concentrations of $\mathrm{Pb}$ (Fig. 2). Consequently, $50 \%$ of the predicted values deviated by $<28 \%$ from the measured concentrations (Table 6). 


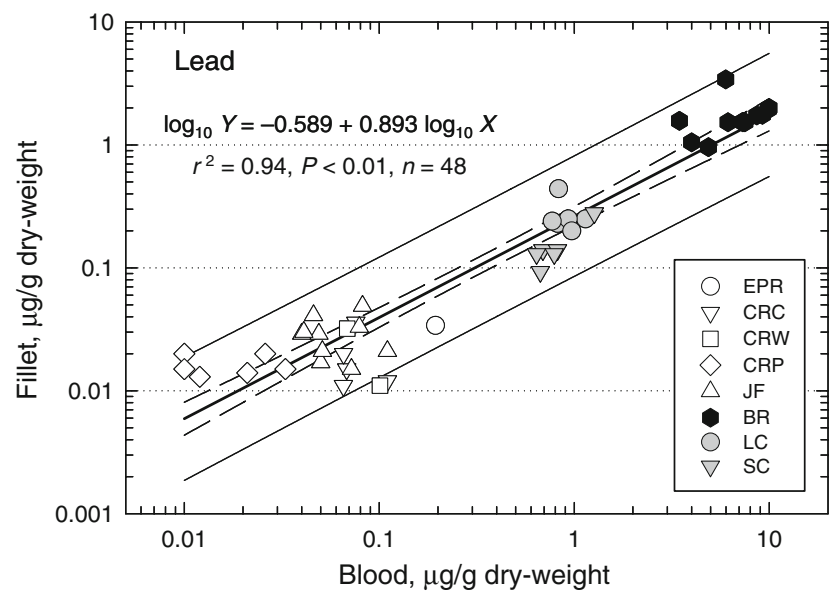

Fig. 2 Fillet $(Y)$ and blood $(X) \mathrm{Pb}$ concentrations in fish from sites in protected areas (open symbols), the Old Lead Belt (solid black symbols), and the Viburnum Trend (gray symbols). Also shown are the linear regression (equation and heavy diagonal line) and its $95 \%$ confidence limits (dashed lines) and 95\% prediction region (light diagonal lines) for all fish from all sites

Fillet $\mathrm{Pb}$ was significantly, but weakly, correlated with fillet $\mathrm{Ca}$ when examined in fish across all sites (Table 5); however, when fish were examined at individual sites, a much stronger relation was evident in fish from BR (Fig 3). In addition, the fish with the greatest fillet $\mathrm{Pb}$ concentration, which was underestimated by the blood $\mathrm{Pb}$ regression, also had the greatest fillet $\mathrm{Ca}$ concentration (Fig 3). A log$\log$ regression between fillet $\mathrm{Pb}$ and $\mathrm{Ca}$ in the 12 fish from $\mathrm{BR}$ explained $63 \%$ of total fillet $\mathrm{Pb}$ variation, but there was no relation between fillet $\mathrm{Pb}$ and $\mathrm{Ca}$ in the 12 fish from $\mathrm{LC}$ and SC (Fig. 3). Concentrations of $\mathrm{Pb}$ in blood and fillet were also correlated with concentrations of several other metals, reflecting their common sources at the mining sites (Table 5).

Fillet $[\mathrm{Pb}] /[\mathrm{Ca}]$ results were similar to those for fillet $\mathrm{Pb}$. Greatest $[\mathrm{Pb}] /[\mathrm{Ca}]$ values were in fish from the mining sites (BR, LC, and SC) whereas the lowest concentrations were in fish from EPR and the ONSR sites (Table 4). Fillet $[\mathrm{Pb}] /$

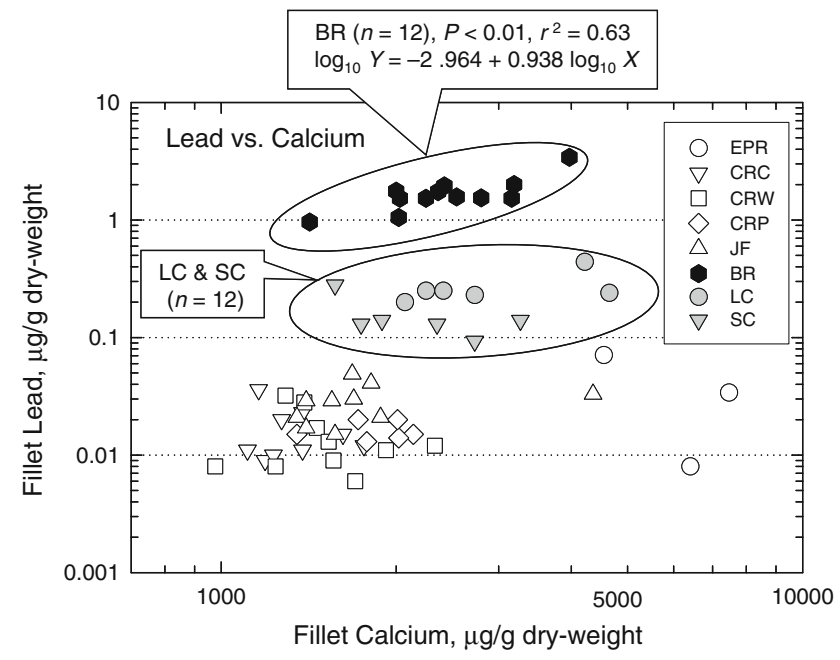

Fig. 3 Fillet $\mathrm{Ca}(X)$ and $\mathrm{Pb}(Y)$ concentrations in fish from sites in protected areas (open symbols), the Old Lead Belt (solid black symbols), and the Viburnum Trend (gray symbols). Upper circled area $=$ all fish from BR and linear regression describing the relation for these fish. Lower circled area $=$ all fish from SC and LC

[Ca] was highly correlated with blood $\mathrm{Pb}$ (Table 5). The relation,

$\log _{10}($ Fillet $[\mathrm{Pb}] /[\mathrm{Ca}])=1.342+0.809 \log _{10}($ Blood Pb $)$,

was statistically significant $(p<0.01)$ and explained $89 \%$ of the total variation in $[\mathrm{Pb}] /[\mathrm{Ca}]$ less than did the model for blood $\mathrm{Pb}$. No other variables were significant after accounting for blood $\mathrm{Pb}$.

Blood and fillet concentrations of $\mathrm{Pb}$, several other metals, and fillet $[\mathrm{Pb}] /[\mathrm{Ca}]$ were negatively correlated with fish size when examined in fish across all sites (Table 5), but relations among fish at the individual sites were not statistically significant. The overall negative relations were artifacts of size-concentration bias resulting from the fact that metal concentrations in the larger fish from the protected areas were lower than those in fish from the mining sites, where concentrations were high.

Table 6 Percent deviation of measured fillet metal concentrations from predicted concentrations based on log-log linear regressions

\begin{tabular}{|c|c|c|c|c|c|c|c|c|c|c|}
\hline \multirow{2}{*}{$\begin{array}{l}\text { Dependent } \\
\text { variable }\end{array}$} & \multirow{2}{*}{$\begin{array}{l}\text { Independent } \\
\text { variable(s) }\end{array}$} & \multirow[t]{2}{*}{ Mean } & \multicolumn{7}{|l|}{ Percentile } & \multirow{2}{*}{$\begin{array}{l}\text { No. of } \\
\text { observations }\end{array}$} \\
\hline & & & 0 (Minimum) & 10 & 25 & 50 & 75 & 90 & 100 (Maximum) & \\
\hline Fillet $\mathrm{Pb}$ & Blood $\mathrm{Pb}$ & 38.8 & 0.3 & 1.7 & 11.8 & 27.6 & 54.9 & 75.2 & 202 & 48 \\
\hline Fillet $\mathrm{Cd}$ & Blood Cd & 47.6 & 0.3 & 4.5 & 14.3 & 26.2 & 64.4 & 120 & 277 & 72 \\
\hline Fillet $\mathrm{Cd}$ & Blood Cd, fillet $\mathrm{Ca}$ & 41.0 & 1.4 & 3.5 & 13.2 & 23.3 & 38.9 & 104 & 257 & 72 \\
\hline Fillet $\mathrm{Co}^{\mathrm{a}}$ & Blood Co & 19.8 & 0.2 & 3.5 & 7.3 & 12.6 & 25.2 & 40.4 & 87.2 & 75 \\
\hline Fillet $\mathrm{Co}^{\mathrm{b}}$ & Blood Co & 18.1 & 0.5 & 3.2 & 7.1 & 12.1 & 25.6 & 38.8 & 88.2 & 74 \\
\hline Fillet Zn & Blood Zn & 15.6 & $<0.1$ & 2.2 & 7.4 & 13.1 & 21.5 & 29.5 & 83.7 & 75 \\
\hline
\end{tabular}

a All data

b With one outlier deleted 
Cadmium

Cd concentrations exceeded the MDL in all blood samples and in fillet samples from 72 fish; all eight sites were represented. Cd concentrations were typically 3- to 4-fold higher in blood than in fillets and were greatest in fish from LC and BR (Table 4). Blood and fillet concentrations were significantly correlated (Table 5); a log-log linear regression containing only blood $\mathrm{Cd}$ explained $61 \%$ of the total variation in fillet $\mathrm{Cd}$ (Fig. 4). The mean difference between predicted and measured $\mathrm{Cd}$ concentrations was $47 \%$, and $50 \%$ of the predicted values deviated by $<27 \%$ (Table 6 ). Inspection of the data indicated that fillet $\mathrm{Cd}$ concentrations in all 3 fish from EPR and in several fish from JF were substantially underestimated as was the concentration in the fish from BR with the highest fillet $\mathrm{Cd}$ concentration (Fig. 4).

Fillet $\mathrm{Cd}$ was also positively correlated with fillet $\mathrm{Ca}$ (Table 5). Consequently, fillet Ca was statistically significant even after accounting for blood $\mathrm{Cd}$. The relation,

$$
\begin{aligned}
\log _{10}(\text { Fillet } \mathrm{Cd})= & -3.397+0.588 \log _{10}(\text { Blood Cd }) \\
& +0.760 \log _{10}(\text { Fillet Ca }),
\end{aligned}
$$

was statistically significant $(p<0.01)$ and explained $73 \%$ of the total variation in fillet $\mathrm{Cd}, 12 \%$ more than blood $\mathrm{Cd}$ alone (Fig. 4). The mean difference between measured and predicted fillet $\mathrm{Cd}$ concentrations decreased to $41.0 \%$ in this relation (Table 6), but several outliers (including the fish from BR) remained evident (data not shown). Nevertheless, $50 \%$ of the predicted values deviated by $<24 \%$ from the measured concentrations (Table 6).

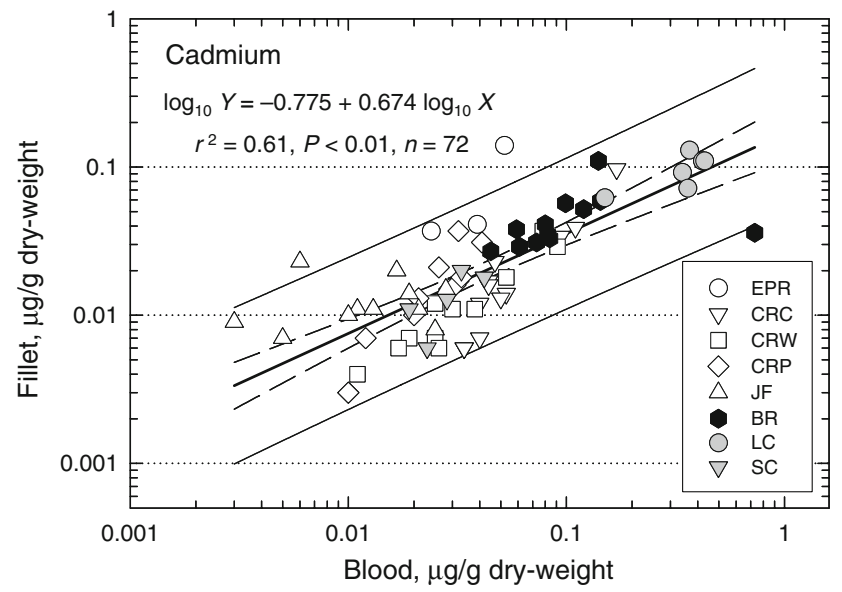

Fig. 4 Fillet $(Y)$ and blood $(X)$ Cd concentrations in fish from sites in protected areas (open symbols), the Old Lead Belt (solid black symbols), and the Viburnum Trend (gray symbols). Also shown are the linear regression (equation and heavy diagonal line) and its $95 \%$ confidence limits (dashed lines) and $95 \%$ prediction region (light diagonal lines) for all fish from all sites
Cobalt, Nickel, and Zinc

Initial inspection of the data indicated that one fillet sample from a protected area site (CRP) contained $1.91 \mu \mathrm{g} / \mathrm{g} \mathrm{dw}$ $\mathrm{Co},>5$-fold higher than concentrations in samples collected downstream from mines and approximately 40-fold higher than the other samples from CRP. Three additional subsamples of this sample were digested and analyzed and found to contain 0.17 to $0.29 \mu \mathrm{g} / \mathrm{g}$ Co. The initial value was replaced with the arithmetic mean of the triplicate reanalyses $(0.24 \mu \mathrm{g} / \mathrm{g})$. Although lower than the initial analysis, the latter value was nevertheless 5-fold higher than all other values from protected areas and was within the range of concentrations in fish from mining sites (Fig. 5). The value was nevertheless retained in the data set.

Co concentrations exceeded the MDL in all samples. Concentrations in blood and fillet were significantly higher at SC than at all other sites, and concentrations in fish from the other mining sites (LC and BR) were greater than those in fish from the protected areas (Table 4). Concentrations were approximately 10-fold higher in blood than in fillets, and concentrations in the two types of samples were highly correlated (Fig. 5 and Table 5). A log-log linear regression that included only blood Co and that was based on all data (including the outlier from CRP) was statistically significant and explained $73 \%$ of the total variation in fillet Co (Fig. 5). The mean difference between predicted and measured fillet Co concentrations based on this regression was $19.8 \%$; $50 \%$ of the predicted values deviated by $<13 \%$; and there were no other obvious outliers (Fig. 5 and Table 6). Without the outlier, the relation,

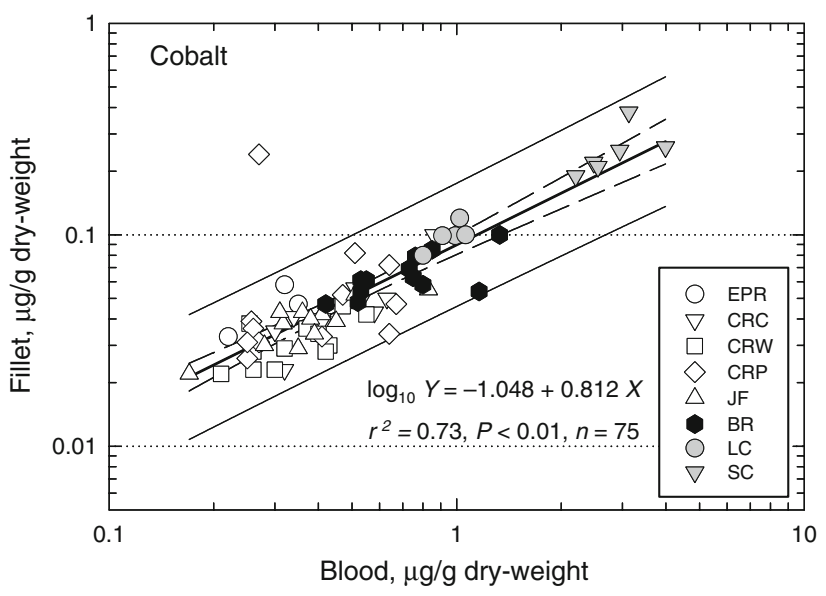

Fig. 5 Fillet $(Y)$ and blood $(X)$ Co concentrations in fish from sites in protected areas (open symbols), the Old Lead Belt (solid black symbols), and the Viburnum Trend (gray symbols). Also shown are the linear regression (equation and heavy diagonal line) and its $95 \%$ confidence limits (dashed lines) and $95 \%$ prediction region (light diagonal lines) for all fish from all sites 
$\log _{10}($ Fillet Co $)=-1.048+0.855 \log _{10}($ Blood Co $)$,

was also significant $(p<0.01)$ and explained $87 \%$ of the total variation in fillet Co. Despite the greater overall precision of this relation, the differences between predicted and measured fillet Co concentrations were similar to those from the relation based on all data (Table 6); the greatest proportional differences were associated with fish in which concentrations were low. In addition, and although fillet Co and $\mathrm{Ca}$ concentrations were correlated (Table 5), neither fillet $\mathrm{Ca}$ nor any other variables were significant in the regressions.

Concentrations of $\mathrm{Ni}$ exceeded the MDL in blood samples from 64 and fillet samples from 62 fish. All eight sites were represented. Concentrations were typically 2- to 4-fold higher in blood than in fillets (Table 4). Blood Ni concentrations were significantly higher in fish from SC and BR than any other sites, but among-site differences in fillet concentrations were not significant (Table 4). Consequently, Ni concentrations in blood and fillets were not significantly correlated nor was fillet $\mathrm{Ni}$ correlated with fillet $\mathrm{Ca}$ (Table 5). The log-log linear relation between blood and fillet concentrations was not significant and explained only $4 \%$ of the total variation in fillet $\mathrm{Ni}$. No other variables were significant.

$\mathrm{Zn}$ concentrations exceeded the MDL in all samples. Concentrations in blood and fillets were approximately the same (Table 4). Although statistically significant, amongsite differences in blood and fillet $\mathrm{Zn}$ concentrations were small compared with the those of other metals (Table 4). Concentrations in blood and fillet were nevertheless significantly correlated, as were fillet $\mathrm{Zn}$ and $\mathrm{Ca}$ (Table 5). The relation,

$\log _{10}($ Fillet Zn $)=-0.827+0.491 \log _{10}($ Blood Zn $)$,

was statistically significant $(p<0.01)$, but it explained only $12 \%$ of the total variation in fillet $\mathrm{Zn}$, and no other variables were significant. Although the mean difference between predicted and measured fillet $\mathrm{Zn}$ concentrations based on this relation was only 15.6 and $50 \%$ of the predicted values differed by $<14 \%$ (Table 6 ), the fit was poor, and there were numerous outliers.

\section{Discussion}

The distribution of $\mathrm{Pb}$ in organisms parallels that of $\mathrm{Ca}$ which, along with $\mathrm{Cd}$ and some other metals, tend to be concentrated in bone, skin, scales, and mucus (Settle and Patterson 1980; Schmitt and Finger 1987; Sauer and Watabe 1989; Ptashynski et al. 2002). The metals may be incorporated into the edible parts of the fish or transferred to them during processing and preparation by contact with slime and contaminated surfaces (Wiener and Giesy 1979; Wiener 1982; Schmitt and Finger 1987). Consequently, the concentration of $\mathrm{Pb}$ and other metals in the "edible parts" depends greatly on how the fish is prepared, handled, and cooked (Schmitt and Finger 1987; Zabik and Zabik 1996; MDHSS 2008).

Blood Sampling for Screening and Monitoring Metals in Hog Sucker

\section{Lead}

Suckers are considered "bony" because of the presence of numerous small intermuscular bones. The regionally preferred method of preparation involves either scoring the scaled "fillets" (with intact skin and bones) or cutting the fillets into small pieces, then deep frying them to soften the bones so they can be eaten. Hog sucker and other catostomids are also benthivorous; they are in frequent contact with bottom sediments, which are ingested in large quantities along with benthic macroinvertebrates, which may also contain sediments (Czarnezki 1985 and references cited therein). Concentrations of $\mathrm{Pb}$ in the edible parts of catostomids and other benthivorous fishes are therefore often higher than in the edible parts of other species typically harvested from mining-contaminated streams (Czarnezki 1985; Gale et al. 2004; Brumbaugh et al. 2005). Accordingly, suckers and other benthivorous fishes are the focus of the current BR consumption advisory (MDHSS 2008).

Based on previous results (Schmitt and Finger 1987), we expected that much of the $\mathrm{Pb}$ in hog sucker fillets from mining-contaminated sites would be explained by their $\mathrm{Ca}$ concentrations. However, this was only true for samples from $\mathrm{BR}$, where $\mathrm{Pb}$ concentrations were highest (Fig. 3). Fillet $\mathrm{Pb}$ concentrations in these samples were more closely correlated with blood $\mathrm{Pb}$ concentrations $(r=0.97$; Table 5) than were blood and fillet concentrations in mixed suckers ( $r=0.80$; Schmitt et al. 1984) or longear sunfish (Lepomis megalotis; $r=0.70$; Dwyer et al. 1988) collected from BR in the 1980s. Our blood and fillet $\mathrm{Pb}$ concentrations were also more closely correlated than blood and "carcass" (i.e., headed, scaled, and eviscerated) $\mathrm{Pb}$ concentrations in common carp (Cyprinus carpio) obtained from BR and other sites in Missouri, Kansas, and Oklahoma in 2001 ( $r=0.88$; Brumbaugh et al. 2005).

Blood $\mathrm{Pb}$ concentrations in hog suckers from within the ONSR (most $<0.1 \mu \mathrm{g} / \mathrm{g} \mathrm{dw}$; Fig. 2) are among the lowest yet reported for catostomids. Blood $\mathrm{Pb}$ concentrations in a mixed-species sample of suckers obtained in 1981 from a BR reference site located upstream of the Old Lead Belt averaged $0.63 \mu \mathrm{g} / \mathrm{g} \mathrm{dw}$ (Schmitt et al. 1984). Similarly, mean blood concentrations were $<0.49$ to $1.22 \mu \mathrm{g} / \mathrm{g} \mathrm{dw} \mathrm{Pb}$ 
in two species of redhorse (Moxostoma spp.) collected from a site within ONSR in 1989 (Schmitt et al. 1993) and averaged $0.24 \mu \mathrm{g} / \mathrm{g} \mathrm{dw}$ in mountain sucker (Catostomus platyrhynchus) from a reference site in Montana (Schmitt et al. 2002). Those measurements were based on atomic absorption spectroscopy and inductively coupled plasma emission spectroscopy and had higher MDLs than those seen with ICP-MS. Using ICP-MS, Schmitt et al. (2007a) reported a mean blood $\mathrm{Pb}$ concentration of $0.28 \mu \mathrm{g} / \mathrm{g} \mathrm{dw}$ in hog suckers collected in 2001 from a Viburnum Trend reference site. The latter value (Schmitt et al. 2007a) is 1.5 times higher than our EPR site mean and 3.7 to 7.0 times higher than our means for ONSR sites even after excluding the censored $(<0.059 \mu \mathrm{g} / \mathrm{g} \mathrm{dw})$ blood $\mathrm{Pb}$ values from consideration (Table 4). Conversely, blood $\mathrm{Pb}$ concentrations in suckers from $\mathrm{Pb}-\mathrm{Zn}$ mining areas in Missouri typically average 1.0 to $10.0 \mu \mathrm{g} / \mathrm{g} \mathrm{dw}$ (Table 4; Schmitt et al. 1984, 1993, 2007a), which are among the highest reported. Consequently, the data set we analyzed represents the probable range of blood and fillet $\mathrm{Pb}$ concentrations for suckers.

The proposed FAO/WHO (1999) MRL of $0.2 \mu \mathrm{g} / \mathrm{g}$ ww $(0.99 \mu \mathrm{g} / \mathrm{g} \mathrm{dw})$ is the lowest relevant fish tissue criterion for $\mathrm{Pb}$; the current MRL is $0.3 \mu \mathrm{g} / \mathrm{g}$ ww $(1.48 \mu \mathrm{g} / \mathrm{g} \mathrm{dw})$, which was also used for the 2008 Missouri consumption advisory (MDHSS 2008). Both values were exceeded by fillet $\mathrm{Pb}$ concentrations in all fish from BR (Figs. 2 and 3), which is consistent with the consumption advisory. Concentrations in some samples from SC and LC also approached the MRL values. Based on the upper 95\% confidence limit of the predicted fillet $\mathrm{Pb}$ concentrations, hog suckers with blood $\mathrm{Pb}$ concentrations $<1.0 \mu \mathrm{g} / \mathrm{g} \mathrm{dw}$ would be expected to have fillet $\mathrm{Pb}$ concentrations $<0.2 \mu \mathrm{g} / \mathrm{g}$ ww $(0.99 \mu \mathrm{g} / \mathrm{g} \mathrm{dw})$, which would be lower than all current or recently proposed standards for $\mathrm{Pb}$ in fish (Fig. 2). These data and data from previous investigations (Schmitt et al. 1984, 1993, 2002, 2007a) also indicate that blood $\mathrm{Pb}$ concentrations $>0.3 \mu \mathrm{g} / \mathrm{g}$ dw in hog sucker would differentiate sites located near or heavily affected by active and historic $\mathrm{Pb}$ sources from reference or minimally affected sites (Fig. 2).

$\mathrm{Pb}$ also represents a potential hazard to piscivorous wildlife and to the fish themselves. In fish, the inhibition of erythrocyte $\delta$-aminolevulinic acid dehydratase (ALA-D; E.C. 4.2.1.24), an enzyme involved in heme synthesis, is currently the most sensitive known response to environmental $\mathrm{Pb}$ exposure (Schmitt et al. 2005, 2007b). Inhibition is directly correlated with blood $\mathrm{Pb}$ concentration and inversely related to blood $\mathrm{Zn}$. Sensitivity varies among taxa; suckers among the most sensitive (Schmitt et al. 2002, 2005). Although there is no apparent threshold, inhibition typically becomes evident in suckers at blood $\mathrm{Pb}$ concentrations of approximately 0.1 to $0.3 \mathrm{mg} / \mathrm{L}$ (Schmitt et al. 1984, 1993, 2007b), or approximately 0.75 to $2.24 \mu \mathrm{g} / \mathrm{g} \mathrm{dw}$ assuming $86.6 \%$ moisture. A blood $\mathrm{Pb}$ concentration $<0.3 \mu \mathrm{g} / \mathrm{g} \mathrm{dw}$ would therefore also identify sites at which effects on fish would be expected based on current information.

Dietary exposure of fish and wildlife to $\mathrm{Pb}$ and other metals is typically evaluated on the basis of concentration in whole fish, which are usually higher than concentrations in fillets (Goldstein and DeWeese 1999). Concentrations of $\mathrm{Pb}$ and some other metals in whole fish are also correlated with concentrations in blood. Based on relations between blood and carcass $\mathrm{Pb}$ concentrations and ALA-D inhibition in Missouri suckers (Schmitt et al. 1993), the NEHC $(1.1 \mu \mathrm{g} / \mathrm{g}$ ww in whole fish; Schmitt et al. 2008) would be associated with a blood $\mathrm{Pb}$ concentration of $0.45 \mathrm{mg} / \mathrm{L}$ or approximately $3.4 \mu \mathrm{g} / \mathrm{g} \mathrm{dw}$ assuming $86.6 \%$ blood moisture. This concentration is several-fold higher than the blood $\mathrm{Pb}$ concentrations associated with either the proposed FAO/WHO MRL $(1.0 \mu \mathrm{g} / \mathrm{g} \mathrm{dw})$ or the onset of ALA-D inhibition $(0.75 \mu \mathrm{g} / \mathrm{g} \mathrm{dw})$.

Among the studies of toxicity to fish reviewed by Jarvinen and Ankley (1999), the lowest reported toxicity benchmark for $\mathrm{Pb}$ in whole fish was $0.4 \mu \mathrm{g} / \mathrm{g}$ ww. This concentration, which was associated with decreased hatchability in third-generation brook trout (Salvelinus fontinalis) embryos (Holcombe et al. 1976), would be achieved at a blood $\mathrm{Pb}$ concentration of $0.17 \mathrm{mg} / \mathrm{L}$ $(1.26 \mu \mathrm{g} / \mathrm{g} \mathrm{dw}$ at $86.6 \%$ moisture), which is also higher than the blood $\mathrm{Pb}$ concentrations associated with ALA-D inhibition and the draft FAO/WHO MRL. Consequently, a blood $\mathrm{Pb}$ screening level of $0.3 \mu \mathrm{g} / \mathrm{g}$ dw would identify mining-affected sites and also be protective of both human and ecological health based on current thresholds and criteria.

\section{Cadmium}

Blood Cd concentrations in hog suckers from the EPR and the ONSR sites were also low compared with fish sampled from mining sites (Table 4). However, and compared with $\mathrm{Pb}$, the concentrations were not appreciably lower than previously reported values for reference sites. Blood $\mathrm{Cd}$ concentrations in hog sucker and redhorse collected within ONSR in 1989 were 0.02 to $0.04 \mu \mathrm{g} / \mathrm{g} \mathrm{dw}$ (Schmitt et al. 1993). Based on available data, concentrations $<0.10$ to $0.15 \mu \mathrm{g} / \mathrm{g} \mathrm{dw}$ appear to be typical for suckers from uncontaminated sites (Schmitt et al. 1993, 2007a). These concentrations are similar to our values from EPR and ONSR (Fig. 4 and Table 4). Conversely, our maximum blood Cd concentrations (mean $0.34 \mu \mathrm{g} / \mathrm{g}$ dw at LC) were substantially lower than some reported previously. A concentration of $1.27 \mu \mathrm{g} / \mathrm{g} \mathrm{dw}$ was reported in a hog sucker collected in 2001 from a Viburnum Trend site (Schmitt 
et al. 2007a), and concentrations in hog suckers collected in 1989 and 1993 downstream from a smelter located near Glover, MO, averaged 1.06 to $3.49 \mu \mathrm{g} / \mathrm{g} \mathrm{dw}$ (Schmitt et al. 1993, 2002).

The correlation between blood and fillet Cd concentrations in hog sucker ( $r=0.78$; Table 5) was identical to the correlation of blood and carcass concentrations in common carp (Brumbaugh et al. 2005). Compared with fillet $\mathrm{Pb}$, which was correlated with fillet $\mathrm{Ca}$ only in fish from the $\mathrm{BR}$, fillet $\mathrm{Cd}$ was significantly correlated with fillet $\mathrm{Ca}$ across all sites (Table 5), and fillet $\mathrm{Ca}$ explained an additional $12 \%$ of the variation in fillet $\mathrm{Cd}$. Both $\mathrm{Pb}$ and $\mathrm{Cd}$ accumulate in organisms in association with $\mathrm{Ca}$ (Settle and Patterson 1980; Pierron et al. 2008).

Fillet $\mathrm{Cd}$ concentrations in hog sucker were all less than the screening values for recreational and subsistence fishers (2.42 and $19.7 \mu \mathrm{g} / \mathrm{g} \mathrm{dw}$, respectively, assuming $79.7 \%$ moisture; USEPA 2000a). Concentrations in all fish from the 2005 and 2007 sites were also $<0.43 \mu \mathrm{g} / \mathrm{g} \mathrm{dw}$, which would classify them as fit for unrestricted human consumption ( $>16$ meals/month) according to current riskedbased criteria (USEPA 2000b). However, fillet $\mathrm{Cd}$ in hog sucker obtained elsewhere in Missouri may represent a greater risk. Based on the upper $95 \%$ prediction limit of the blood-to-fillet Cd relation (Fig. 4), the hog sucker collected in 2001 from the Viburnum Trend, in which the blood Cd concentration was $1.27 \mu \mathrm{g} / \mathrm{g} \mathrm{dw}$ (Schmitt et al. 2007a), could have had a fillet $\mathrm{Cd}$ concentration $>1.0 \mu \mathrm{g} / \mathrm{g} \mathrm{dw}$ $(0.21 \mu \mathrm{g} / \mathrm{g}$ ww assuming $79.7 \%$ moisture $)$, which would warrant restriction to 12 meals/month according to current criteria (USEPA 2000b). Hog suckers collected downstream from the Glover smelter in 1993, which had blood Cd concentrations $>3.49 \mu \mathrm{g} / \mathrm{g} \mathrm{dw}$, would have had proportionally higher fillet concentrations that were beyond the range of our regression relation (Fig. 4).

$\mathrm{Cd}$ in fish can also represent a risk to both piscivorous wildlife and the fish. A wildlife NEHC of $1.0 \mu \mathrm{g} / \mathrm{g}$ ww was estimated for $\mathrm{Cd}$ using food chain analysis and toxicity reference values (Schmitt et al. 2008). Benchmark concentrations in whole fish for toxicity to the fish or to wildlife fish consumers are typically 2.0 to $15.0 \mu \mathrm{g} / \mathrm{g} \mathrm{ww}$ (Eisler 1985; Jarvinen and Ankley 1999). Concentrations of $\mathrm{Cd}$ in whole fish from BR and streams draining the Viburnum Trend have not typically exceeded these thresholds, but the mean concentrations in whole hog suckers collected downstream of the Glover smelter were $1.18 \mu \mathrm{g} / \mathrm{g}$ ww in 1989 (Schmitt et al. 1993) and 1.32 to $1.82 \mu \mathrm{g} / \mathrm{g}$ ww in 1993 (Schmitt et al. 2002), all of which exceeded the NEHC. Concentrations of $\mathrm{Pb}$ and $\mathrm{Cd}$, but not $\mathrm{Zn}$, in "carcass" (headed, scaled, eviscerated) samples of common carp (Cyprinus carpio) can be estimated from concentrations in blood (Brumbaugh et al. 2005). It is therefore likely that concentrations of these metals in whole hog sucker and other benthivores can also be estimated from blood concentrations, but additional analyses would be required to develop and evaluate the relations.

In addition to the generally low concentrations, and compared with $\mathrm{Pb}$, concentrations of $\mathrm{Cd}$ overlapped considerably among sites (Fig. 4). Defining screening criteria based on blood concentrations is therefore more difficult. Nevertheless, hog sucker with blood $\mathrm{Cd}$ concentrations $<0.5 \mu \mathrm{g} / \mathrm{g} \mathrm{dw}$ would probably have fillet and whole-body $\mathrm{Cd}$ concentrations that did not represent a threat to human or ecologic health. Although a blood $\mathrm{Cd}$ concentration $>0.1 \mu \mathrm{g} / \mathrm{g} \mathrm{dw}$ might indicate that the fish inhabited a mining-affected site, concentrations were lower in some hog suckers from mining-affected sites (Fig. 4).

\section{Zinc, Nickel, and Cobalt}

Internal concentrations of $\mathrm{Zn}$, an essential element, are tightly regulated by fish (Bury et al. 2003). Accordingly, the range of blood and fillet concentrations in hog suckers was comparatively narrow (Table 4) relative to the range of exposure concentrations represented by the sites (Brumbaugh et al. 2007). A previous study found that $\mathrm{Zn}$ concentrations in blood and whole fish samples of hog sucker and other suckers varied by only approximately 2fold, although concentrations in sediments ranged more than 4 orders of magnitude (Schmitt et al. 1993). Consequently, and although $\mathrm{Zn}$ concentrations in fish from mining sites are typically higher than those from sites not affected by mining, the differences are proportionally small compared with $\mathrm{Pb}$ and some other metals. Blood $\mathrm{Zn}$ is therefore a comparatively poor indicator of fish exposure to mining-derived $\mathrm{Zn}$ except at very high concentrations.

$\mathrm{Co}$ and $\mathrm{Ni}$ are also essential elements. Although they are regulated by higher vertebrates (e.g., Eisler 1998), Ni and Co are not as well regulated as $\mathrm{Zn}$ by fish (Schmitt et al. 2007a). Mean blood Ni concentrations in hog suckers from ONSR sites and EPR were $<0.20 \mu \mathrm{g} / \mathrm{g} \mathrm{dw}$, which is similar to previously reported concentrations in suckers from reference sites (Schmitt et al. 1993, 2007a). Conversely, blood $\mathrm{Ni}$ concentrations as much as 5-fold higher than our SC values were reported in hog suckers collected further upstream in 2001 (Schmitt et al. 2007a). Liver Ni concentrations were also increased in the 2001 fish from SC but were only approximately $50 \%$ of the blood concentrations (Schmitt et al. 2007a). Most of the Ni in fish is associated with blood plasma (Pane et al. 2004); concentrations are therefore higher in blood than in liver (Schmitt et al. 2007a). Ni concentrations in muscle are typically low, even in fish (including suckers) from Ni-contaminated waters (Bradley and Morris 1986; Heit et al. 1989; Goldstein and DeWeese 1999; Ptashynski and Klaverkamp 2002). The greatest concentrations tend to occur in kidney 
and scales, but concentrations are also comparatively high in skin and bone. It is therefore possible for $\mathrm{Ni}$ concentrations in fillets containing skin and bone obtained from fish inhabiting contaminated waters to be considerably higher than concentrations in muscle. However, concentrations in our fillet samples were uniformly low and were not correlated with $\mathrm{Ca}$ concentrations (Table 5). Blood Co concentrations in hog suckers from EPR and ONSR were also similar to concentrations in fish collected in 2001 from the Viburnum Trend reference site (Schmitt et al. 2007a), and concentrations in fish from SC and the other mining sites were increased relative to EPR and ONSR (Table 4). Blood Co concentrations in hog suckers collected in 2001 further upstream on SC were approximately twice what we detected. In addition, and compared with $\mathrm{Ni}$, Co concentrations in blood and liver samples were approximately equal (Schmitt et al. 2007a). Also compared with Ni, blood and fillet $\mathrm{Co}$ concentrations were correlated (Table 5). Concentrations of $\mathrm{Co}, \mathrm{Ni}$, and $\mathrm{Zn}$ may also be higher in whole fish than in fillets and could therefore also represent a risk to piscivorous wildlife in the Viburnum Trend and other areas of southeastern Missouri where these metals were mined (Proctor and Sinha 1978). Further investigation would be required to assess these possibilities.

In terms of screening levels, blood Co concentrations $>1.0 \mu \mathrm{g} / \mathrm{g} \mathrm{dw}$ and blood Ni concentrations $>0.2 \mu \mathrm{g} / \mathrm{g} \mathrm{dw}$ would identify hog suckers from sites heavily affected by mining, but there was considerable overlap among reference and minimally affected sites. As noted, blood $\mathrm{Zn}$ is not a reliable indicator of environmental exposure; although concentrations in fish from the most heavily contaminated sites are typically $>70 \mu \mathrm{g} / \mathrm{g} \mathrm{dw}$, this concentration was exceeded by one fish from the JF, which is within the ONSR.

\section{Blood Sampling Compared With Other Nonlethal Sampling Strategies}

Blood sampling offers some substantial advantages to available alternatives for nonlethal monitoring of metals in fish. Biopsy samples have been used to determine $\mathrm{Hg}$ in piscivorous fishes (Schmitt and Brumbaugh 2007c and references cited therein) and for Se in the federally listed razorback sucker (Xyrauchen texanus; Waddell and May 1995). Fin clips have been proposed for monitoring $\mathrm{Hg}$ (Rolfhus et al. 2008), as have analyses of scales or fin spines, which contain proportionally large amounts of $\mathrm{Ca}$, to monitor other metals (e.g., Sauer and Watabe 1989; Ptashynski et al. 2002). $\mathrm{Hg}$ and Se accumulate in fish muscle, which facilitates biopsy sampling. Skin is generally not included in biopsy samples analyzed for metals (Schmitt and Brumbaugh 2007). In contrast, Pb, Cd, and other metals accumulate in bone, skin, or both. Although we are not aware of studies that have evaluated biopsy sampling for the metals we measured, we suspect that the presence of skin or bone fragments in the small-mass samples generated by biopsy instruments would result in substantial among-sample variation. Scales accumulate $\mathrm{Zn}$, $\mathrm{Pb}, \mathrm{Ni}$, manganese, and strontium, but not $\mathrm{Cd}$ or copper (Sauer and Watabe 1989; Yoshitomi et al. 1998; Ptashynski et al. 2002). Concentrations of $\mathrm{Pb}$ in fin spines are also enriched and have been shown to be correlated with concentrations in otoliths (Gillanders 2001). However, scales and spines may be reabsorbed or remineralized with time during periods of environmental stress (Gillanders 2001). The flux of metals in scales and mucus is also bidirectional; metals can be secreted into them by the fish or sequestered by them from the water (Coello and Khan 1996 and references cited by Schmitt and Finger 1987). Finally, regenerated scales occur often in suckers and many other fishes. Consequently, and although scales and other hard structures have been proposed as continuous recorders of environmental metal exposure, the utility of these structures and of biopsy samples for monitoring mining-derived metals in suckers remains to be evaluated.

Blood has several additional advantages compared with other target tissues. First, an increased metal concentration in blood may better indicate the current exposure and health of an organism. In contrast, sequestration of metals in target tissues, such as bone or liver, represents a longterm biologic detoxification mechanism (Martin 1987). As such, concentrations in these tissues may represent longterm cumulative exposure history but may not accurately reflect current or recent exposure or effects on the organism. Consequently, blood $\mathrm{Pb}$ remains an important indicator of $\mathrm{Pb}$ exposure in humans (Barbosa et al. 2005) and wildlife (Pattee and Pain 2003; Henny 2003). Second, metal concentrations in blood seem to be less variable (among samples and fish) than in other tissues (Brumbaugh et al. 2005; Schmitt and Brumbaugh 2007), and fewer samples are required to achieve the same relative precision. Third, blood is generally less costly to analyze than other tissues, and sample contamination is less likely. Blood collection and storage requirements are simpler; less equipment and fewer containers are used; and homogenization is not required. These factors also decrease the risk of contamination. Sampling contamination is also less likely to happen in blood collected with a needle and syringe than for tissues obtained by dissection (Schmitt and Finger 1987). $\mathrm{Pb}$ is a ubiquitous, pervasive contaminant; measurement in environmental samples at low concentrations is inherently difficult (Settle and Patterson 1980; Windom and Duce 1991; Benoit 1994). We detected lowlevel blank contamination in one group of samples, which was ultimately traced to some vials. This low-level contamination was reflected in higher MDLs (Table 2), which 
were nevertheless lower than those reported in previous studies. If not for the fact that blood $\mathrm{Pb}$ concentrations in fish from the EPR and ONSR system were 10-fold lower than previously reported concentrations in fish from reference sites in the Midwest (including laboratory-raised fish; Schmitt et al. 2005, 2007a), the censoring level would not have been an issue. Finally, repeated sampling of blood from large fish, which are less plentiful and often more valued by recreational fishers and fish consumers, is feasible because it is not necessary to kill the fish.

Although blood sampling appears attractive for monitoring mining-derived metals in suckers and possibly other fishes, there are at least two potential drawbacks. First, as indicated, the biologic half-life of $\mathrm{Pb}$ and other metals in blood is comparatively short; it ranges from several days to several weeks. In contrast, other tissues̄such as liver, kidney, bone, or axial musclētend to be more cumulative metal repositories (Savory et al. 1987; Pattee and Pain 2003). Therefore, although blood concentrations may accurately portray recent or current exposure, they may poorly indicate the long-term exposure history of an organism if the exposure has been variable. Blood may therefore be less suitable for monitoring in situations where exposure is intermittent or temporally variable. Seasonal variation related to the reproductive cycle, fish movement, or both may also occur. However, the comparability of the blood metal concentrations we report, relative to those of the previous studies cited, indicate that for situations where exposure derives from mining-related sources, blood concentrations accurately reflect exposure. The second negative feature is that the blood and fillet concentrations are not directly comparable. Compared with biopsy methods, which yield samples that are essentially subsamples of fillets that contain comparable metal concentrations, fillet concentrations must be estimated from blood samples on the basis of regression relations, which contain additional error components and must be re-evaluated periodically (Schmitt and Brumbaugh 2007). It should also be noted that the actual precision of the fillet estimates is less than we indicated because error in the blood measurements was not accounted for (Ricker 1973; Hensler and Stout 1982; Lake et al. 2006). The estimates may therefore lack the precision necessary for establishing consumption advisories.

\section{Conclusion}

Blood sampling is practical and useful for estimating concentrations of $\mathrm{Pb}$ and $\mathrm{Cd}$ in the edible parts of hog suckers, as shown previously for other species and metals (Brumbaugh et al. 2007; Schmitt and Brumbaugh 2007). Although relative differences between predicted and measured concentrations were proportionally large for some samples (Table 6), many of the greatest proportional deviations were associated with low concentrations; relative differences were smaller in the upper (and presumably more relevant) parts of the concentration ranges. In addition, and compared with $\mathrm{Hg}$, concentrations of the metals we measured in hog sucker blood and fillets did not differ appreciably with fish size, thus eliminating a potentially important source of bias and variation inherent in monitoring studies. Sex differences were also not evident; however, size and sex differences may be more important during other seasons caused by variation associated with the reproductive cycle. Although the relations between blood and fillet $\mathrm{Pb}$ and $\mathrm{Cd}$ concentrations may lack the precision necessary for establishing consumption advisories, hog suckers with blood $\mathrm{Pb}$ concentrations $<0.3 \mu \mathrm{g} / \mathrm{g}$ $\mathrm{dw}$ would be safe to eat and would not represent a risk to piscivorous wildlife. This concentration would also differentiate between fish from sites that are heavily contaminated by mining and those from reference or moderately contaminated sites. Blood concentrations of $\mathrm{Cd}, \mathrm{Co}$, and $\mathrm{Ni}$ can also be used for monitoring and to identify potential sites for fillet sampling, which would decrease the number of fish that need to be killed.

Acknowledgments This study was supported by the Park-Oriented Biologic Support Project, a partnership between the United States Geological Survey Status and Trends of Biologic Resources Program and the NPS; and by the USGS Contaminants Biology Program. Fish were collected under the supervision of J. Ackerson, D. Mayer, R. Legler, P. Cieslewicz, and M. Reed (all MDC); M. McKee (also MDC) coordinated the collections. V. Grant, M. Gossett, J. Luraas, and E. Kunz (all NPS), and M. Mac, J. Besser, B. Poulton, D. Stoppler, and S. Olson (all USGS) assisted in the field. J. Arms, M. Walther, S. Koppi, and V. Melton (all USGS) assisted in the laboratory. W. Simpson and D. Noltie (both from the University of Missouri-Columbia) prepared and read the scales, M. Struckhoff (USGS) prepared the map, and M. McKee (MDC) and M. Hooper (USGS) provided useful comments on an earlier version of the manuscript.

\section{References}

Allert AL, Fairchild JF, DiStefano RJ, Schmitt CJ, Besser JM, Brumbaugh WG et al (2008) Effects of lead-zinc mining on crayfish (Orconectes hylas) in the Black River watershed, Missouri. Freshw Crayfish 16:99-113

Allert AL, Fairchild JF, DiStefano RJ, Schmitt CJ, Brumbaugh WG, Besser JM (in press) Ecological effects of lead mining on Ozark streams: In-situ toxicity of metals to Orconectes hylas. downstream of mine sites in the Black River drainage, Missouri, USA. Ecotoxicol Environ Saf

ASIH, AFS, AIFRB (2004) Guidelines for use of fishes in field research. American Fisheries Society, Bethesda, MD. http:// www.fisheries.org/afs/docs/policy_guidelines2004.pdf

Australia New Zealand Food Authority (2002) Food Standards Code, Standard 1.4.1, Contaminants and Natural Toxicants: 78. http:// www.foodstandards.gov.au/_srcfiles/fsc_1_4_1_Contaminants_ v78.pdf 
Barbosa FB Jr, Tanus-Santos JE, Gerlach RF, Parsons PJ (2005) A critical review of biomarkers used for monitoring human exposure to lead: Advantages, limitations, and future needs. Environ Health Perspect 113:1669-1674

Benoit G (1994) Clean technique measurement of $\mathrm{Pb}, \mathrm{Ag}$, and $\mathrm{Cd}$ in freshwater: a redefinition of metal pollution. Environ Sci Technol 28:1987-1991

Besser JM, Brumbaugh WG, May TW, Schmitt CJ (2007) Biomonitoring of lead, zinc, and cadmium in streams draining leadmining and non-mining areas, southeast Missouri. Environ Monit Assess 129:227-241

Besser JM, Brumbaugh WG, Allert AL, Poulton BC, Schmitt CJ, Ingersoll CG (2009) Ecological impacts of lead mining on Ozark streams: Toxicity of sediment pore water. Ecotoxicol Environ Saf 72:516-526

Bradley RW, Morris JR (1986) Heavy metals in fish from a series of metal-contaminated lakes near Sudbury, Ontario. Water Air Soil Pollut 27:341

Brumbaugh WG, Schmitt CJ, May TW (2005) Concentrations of cadmium, lead, and zinc in fish from mining-influenced waters of Northeastern Oklahoma: sampling of blood, carcass, and liver for aquatic biomonitoring. Arch Environ Contam Toxicol 49:76-88

Brumbaugh WG, May TW, Besser JM, Allert AL, Schmitt CJ (2007) Assessment of elemental concentrations in streams of the New Lead Belt in southeastern Missouri, 2002-05. United States Geological Survey Scientific Investigations Report 2007-5057, $57 \mathrm{pp}$

Bury NR, Walker PA, Glover CN (2003) Nutritive metal uptake in teleost fish. J Exp Biol 206:11-23

Coello WF, Khan MAQ (1996) Protection against heavy metal toxicity by mucus and scales in fish. Arch Environ Contam Toxicol 30:319-326

Czarnezki J (1985) Accumulation of lead in fish from Missouri streams impacted by lead mining. Bull Environ Contam Toxicol 34:736-745

Dural M, Göksu MZL, Őzak AA, Derici B (2006) Bioaccumulation of some heavy metals in different tissues of Dicentrarchus labrax L, 1758, Sparaus aurata L, 1758, and Mugil cephalus L, 1758 from the Camlik Lagoon of the eastern coast of Mediterranean (Turkey). Environ Monit Assess 118:65-74

Dwyer FJ, Schmitt CJ, Finger SE, Mehrle PM (1988) Biochemical changes in longear sunfish, Lepomis megalotis, associated with lead, cadmium and zinc from mine tailings. J Fish Biol 33:307-317

Eisler R (1985) Cadmium hazards to fish, wildlife, and invertebrates: A synoptic review. United States Fish and Wildlife Service, Biological Report 85(1.2), $46 \mathrm{pp}$

Eisler R (1998) Nickel hazards to fish, wildlife, and invertebrates: a synoptic review. United States Geological Survey, Contaminant Hazard Reviews Report No. 34, Biological Science Report USGS/BRD/BSR-1998-001, 95 pp

FAO (Food and Agricultural Organization of the United Nations) (1983) Compilation of legal limits for hazardous substances in fish and fishery products. FAO Circular 464 764:5-100

FAO/WHO (Food and Agricultural Organization of the United Nations and World Health Organization) (1998) Discussion paper on cadmium. Codex Alimentarius Commission, Joint FAO/WHO Food Standards Programme, Codex Committee on Food Additives and Contaminants, CX/FAC 99/21, The Hague, The Netherlands, 10 pp. http://www.who.int/fsf/Chemicalcontaminants/cadmium

FAO/WHO (Food and Agricultural Organization of the United Nations and World Health Organization) (1999) Draft maximum levels for lead. Codex Alimentarius Commission, Joint FAO/ WHO Food Standards Programme, Codex Committee on Food Additives and Contaminants. CX/FAC 00/24, The Hague, The Netherlands, 20 pp. http://www.who.int/fsf/Chemical contaminants/lead
FAO/WHO (Food and Agricultural Organization of the United Nations and World Health Organization) (2007) Codex general standard for contaminants and toxins in foods. Codex Standard 193-1995, Rev 3-2007. Codex Alimentarius Commission, Joint FAO/WHO Food Standards Programme, Codex Committee on Food Additives and Contaminants, The Hague, The Netherlands, $46 \mathrm{pp}$. http://www.codexalimentarius.net/download/standards/ 17/CXS_193e.pdf

Gale N, Adams CD, Wixson BF, Loftin KA, Huang YW (2004) Lead, zinc, copper, and cadmium in fish and sediments from the Big River and Flat River Creek of Missouri's Old Lead Belt. Environ Geochem Health 26:37-49

Gillanders BM (2001) Trace metals in four structures of fish and their use for estimates of stock structure. Fish Bull 99:410-419

Goldstein RM, DeWeese LR (1999) Comparison of trace element concentrations in tissue of common carp and implications for monitoring. J Am Water Resour Assoc 35:1133-1140

Gremillion PT, Cizdziel JV, Cody NR (2005) Caudal fin mercury as a non-lethal predictor of fish-muscle mercury. Environ Chem 2:96-99

Heit M, Schofield C, Driscoll CT, Hodgkiss SS (1989) Trace element concentrations in fish from three Adirondack lakes with different $\mathrm{pH}$ values. Water Air Soil Pollut 44:9-30

Henny CJ (2003) Effects of mining lead on birds: a case history at Coeur d'Alene Basin, Idaho. In: Hoffman DJ, Rattner BA, Burton GA Jr, Cairns J Jr (eds) Handbook of ecotoxicology. Lewis, Boca Raton, FL, pp 755-766

Hensler G, Stout W (1982) Use of blood levels to infer carcass levels of contaminants. Arch Environ Contam Toxicol 11:235-238

Holcombe GW, Benoit DA, Leonard EN, McKim JM (1976) Longterm effects of lead exposure on three generations of brook trout (Salvelinus fontinalis). J Fish Res Bd Can 33:1731-1741

Imes JL, Plummer NL, Kleeschulte MJ, Schumacher JG (2007) Recharge area, base-flow and quick-flow discharge rates and ages, and general water quality of Big Spring in Carter County, Missouri, 2000-04. United States Geological Survey Scientific Investigations Report 2007-5049, 80 pp

Jarvinen AW, Ankley GT (1999) Linkage of effects to tissue residues: development of a comprehensive database for aquatic organisms exposed to inorganic and organic chemicals. Society of Environmental Toxicology and Chemistry, Pensacola, FL, p 364

Jearld A Jr (1983) Age determination. In: Nielsen LA, Johnson DL (eds) Fisheries techniques. American Fisheries Society, Bethesda, MD, pp 301-324

Lake JL, Ryba SA, Servst JR, Libby AD (2006) Mercury in fish scales as an assessment method for predicting muscle tissue mercury concentrations in largemouth bass. Arch Environ Contam Toxicol 50:539-544

Leblond C, Mephara J, Sauvė (2008) Trace metals (Cd, Co, Cr, Cu, $\mathrm{Hg}, \mathrm{Ni}, \mathrm{Pb}$, and $\mathrm{Zn}$ ) in food supplements of marine origin. Human Ecol Risk Assess 14:408-420

Martin RB (1987) Bioinorganic chemistry of toxicity. In: Seiler HG, Sigel H, Sigel A (eds) Handbook on toxicity of inorganic compounds. Marcel Dekker, New York, NY, pp 9-25

Missouri Department of Health and Senior Services (MDHSS) (2008) 2008 fish advisory. A guide to eating fish in Missouri. Jefferson City, MO, p 11

Pane EF, Haque Z, Goss GG, Wood CM (2004) Mechanistic analysis of acute, $\mathrm{Ni}$-induced respiratory toxicity in the rainbow trout (Oncorhynchus mykiss): an exclusively branchial phenomenon. Aquat Toxicol 69:11-24

Pattee OH, Pain DH (2003) Lead in the environment. In: Hoffman DJ, Rattner BA, Burton GA Jr, Cairns J Jr (eds) Handbook of ecotoxicology. Lewis Publishers, Boca Raton, FL, pp 373-408

Petersen JC, Adamski MC, Bell RW, Davis JV, Femmer SR, Freiwald DA et al (1998) Water quality in the Ozark Plateus Arkansas 
Kansas Missouri and Oklahoma 1992-95. United States Geological Survey Circular 1158:33

Pierron F, Baurdrimont M, DuFour S, Elie P, Bossy A, Baloche NM$D$ et al (2008) How cadmium could compromise the completion of the European eel's reproductive migration. Environ Sci Technol 42:4607-4612

Proctor PD, Sinha B (1978) Cobalt-nickel-cadmium mobilization, transportation and fixation in surface waters, stream sediments and selected aquatic life in the Fredericktown Co-Ni Metallogenic Province, Southeast Missouri. In: Hemphill DD (ed) Proceedings of the twelfth symposium on trace substances in environmental health (vol. XII), Columbia, MO, June 6-8, pp 119-128

Ptashynski MD, Klaverkamp JF (2002) Accumulation and distribution of dietary nickel in lake whitefish (Coregonus clupeaformis). Aquat Toxicol 58:249-264

Rashed MN (2001a) Monitoring of environmental heavy metals in fish from Nasser Lake. Environ Int 27:27-33

Rashed MN (2001b) Cadmium and lead levels in fish (Tilapia nilotica) tissues as biological indicator for lake water pollution. Environ Monit Assess 68:75-89

Ricker WE (1973) Linear regressions in fishery research. J Fish Res Bd Can 30:409-434

Rolfhus KR, Sandheinrich MB, Wiener JG, Bailey SW, Thorseson KA, Hammerschmidt CR (2008) Analysis of fin clips as a nonlethal method for monitoring mercury in fish. Environ Sci Technol 42:871-877

Sauer GR, Watabe N (1989) Temporal and metal-specific patterns in the accumulation of heavy metals by the scales of Fundulus heteroclitus. Aquat Toxicol 14:233-248

Savory J, Bertholf RL, Wills MR (1987) In: Seiler HG, Sigel H, Sigel A (eds) Handbook on toxicity of inorganic compounds. Marcel Dekker, New York, NY, pp 29-31

Schmitt CJ, Brumbaugh WG (2007) Evaluation of potentially nonlethal sampling methods for monitoring mercury concentrations in smallmouth bass (Micropterus dolomieu). Arch Environ Contam Toxicol 53:84-95

Schmitt CJ, Finger SE (1987) The effects of sample preparation on the measured concentrations of eight elements in the edible tissues of fish contaminated by lead mining. Arch Environ Contam Toxicol 16:185-207

Schmitt CJ, Dwyer FJ, Finger SE (1984) Erythrocyte $\delta$-aminolevulinic acid dehydratase (ALA-D) activity as an indicator of $\mathrm{Pb}$ and $\mathrm{Zn}$ bioavailability in a river contaminated by mine tailings. Can J Fish Aquat Sci 41:1030-1040

Schmitt CJ, Wildhaber ML, Hunn JB, Nash T, Tieger MN, Steadman BL (1993) Biomonitoring of lead-contaminated Missouri streams with and assay for erythrocyte $\delta$-aminolevulinic acid dehydratase (ALA-D) activity in fish blood. Arch Environ Contam Toxicol 25:464-475

Schmitt CJ, Caldwell CA, Olsen B, Serdar D, Coffey M (2002) Inhibition of erythrocyte $\delta$-aminolevulinc acid dehydratase (ALAD) activity in fish from waters affected by smelters. Environ Monit Assess 77:99-119

Schmitt CJ, Whyte JJ, Brumbaugh WG, Tillitt DE (2005) Biochemical effects of lead, zinc, and cadmium from mining on fish in the Tri-States District of Northeastern Oklahoma. Environ Toxicol Chem 24:1483-1495

Schmitt CJ, Brumbaugh WG, Linder GL, Hinck JE (2006) A screening-level assessment of lead, cadmium, and zinc in fish and crayfish from northeastern Oklahoma, USA. Environ Geochem Health 28:445-471

Schmitt CJ, Brumbaugh WG, May TW (2007a) Accumulation of metals in fish from lead-zinc mining areas of southeastern Missouri, USA. Ecotoxicol Environ Saf 67:14-30

Schmitt CJ, Whyte JJ, Roberts AP, Annis ML, May TW, Tillitt DE (2007b) Biomarkers of metal exposure in fish from lead-zinc mining areas of southeastern Missouri, USA. Ecotoxicol Environ Saf $67: 31-47$

Schmitt CJ, Brumbaugh WG, Besser JM, Hinck JE, Bowles DE, Morrison LW, et al (2008) Protocol for monitoring elemental contaminants in Ozark National Scenic Riverways, Missouri: Version 1.0. United States Geological Survey, Open-File Report 2008-1269, $42 \mathrm{pp}$

Settle DM, Patterson CC (1980) Lead in albacore: guide to lead pollution in Americans. Science 207:1167-1176

Sidwell VD, Loomis AL, Loomis KJ, Foncannon PR, Buzzell D (1978) Composition of the edible portion of raw (fresh or frozen) crustaceans, finfish, and mollusks. III. Microelements. Mar Fish Rev 40. Paper 1324:1-20

USEPA (United States Environmental Protection Agency) (1994) Technical support document for the Integrated Exposure Uptake Biokinetic Model for lead in children (v0.99d), NTIS No. PB94963505. EPA 9285:7-22

USEPA (United States Environmental Protection Agency) (2000a) Report to Congress: EPA studies on sensitive subpopulations and drinking water contaminants. Office of Water, Washington, DC, EPA 815-R-00-015

USEPA (United States Environmental Protection Agency) (2000b) Guidance for assessing chemical contaminant data for use in fish advisories. Volume 2: Risk assessment and fish consumption limits, 3rd ed, EPA 823-B-00-008. Office of Water, Washington, DC. http://www.epa.gov/ost/fish/advice/volume2/

USFDA (United States Food and Drug Administration) (2000) Action levels for poisonous or deleterious substances in human food and animal feed. Industry Activities Staff Booklet, Washington, DC. http://www.cfsan.fda.gov/\&sim;lrd/fdaact.html\#cadm

USFDA (United States Food and Drug Administration) (2001) Environmental chemical contaminants and pesticides (a chemical hazard). In: Fish and fisheries products, hazards and control guidance, 3rd ed. Center for Food Safety and Applied Nutrition, Washington, DC, pp 105-124. http://www.cfsan.fda.gov/ \&sim;acrobat/haccp4i.pdf

Van Oostdam J, Gilman A, Dewailly E, Usher P, Wheatley B, Kuhnlein $\mathrm{H}$ et al (1999) Human health implications of environmental contaminants in Arctic Canada: A review. Sci Total Environ 230:1-82

Vos G, Hovens JPC, Hagel P (1986) Chromium, nickel, copper, zinc, arsenic, selenium, cadmium, mercury and lead in Dutch fishery products 1977-1984. Sci Total Environ 52:25-40

Waddell B, May T (1995) Selenium concentrations in the razorback sucker Xyrauchen texanus): substitution of non-lethal muscle plugs for muscle tissue in contaminant assessment. Arch Environ Contam Toxicol 28:321-326

Watanabe KH, Desimone FW, Thiyagarajaha A, Hatrley WR, Hindrichs AE (2003) Fish tissue quality in the lower Mississippi River and health risks from fish consumption. Sci Total Environ 302:109-126

Wiener JG (1982) Method for detecting trace-element contamination of fish samples from handling. Environ Sci Technol 16:90-93

Wiener JG, Giesy JP Jr (1979) Concentrations of Cd, Cu, Mn, Pb, and $\mathrm{Zn}$ in fishes in a highly organic softwater pond. J Fish Res Bd Can 36:270-279

Wixson BG (1978) Biogeochemical cycling of lead in the New Lead Belt of Missouri. In: Nriagu JO (ed) The biogeochemical cycling of lead in the environment, part A. Ecological cycles. Elsevier/North Holland Biomedical Press, Amsterdam, The Netherlands, pp 119-136

Yoshitomi T, Nakayasu C, Hasegawa S, Iida A, Okamoto N (1998) Site-specific lead distribution in scales of lead-administered carp (Cyprinus carpio) by non-destructive SR-XRF analysis. Chemosphere 36:2305-2310

Zabik ME, Zabik MJ (1996) Influence of processing on environmental contaminants in foods. Food Technol 50:225-229 